\title{
A review of properties, nutritional and pharmaceutical applications of Moringa oleifera: integrative approach on conventional and traditional Asian medicine
}

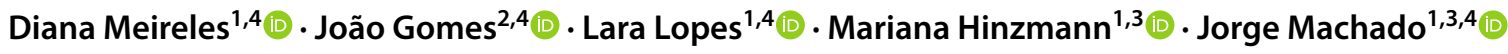

Received: 20 August 2019 / Accepted: 1 June 2020 / Published online: 17 August 2020

(c) Institute of Korean Medicine, Kyung Hee University 2020

\begin{abstract}
Moringa oleifera L. from the Moringaceae family is a perennial tree widely cultivated in many tropic regions and easily grown even in adverse conditions. M. oleifera is also known as the miracle tree, which for centuries has been indicated for traditional medicine. With no reports of side effects, in doses achievable by ingestion, different parts of M. oleifera is used to treat several conditions, such as malnutrition, diabetes, blindness, anemia, hypertension, stress, depression, skin, arthritis, joints and kidney stones disorders. This plant also showed capacity of helping in maintenance of the cardiovascular system health, blood-glucose levels and providing anti-oxidant, anti-inflammatory and anti-cancer activity as well as the regulation of urinary tract and lactation in nursing women. The seed and leaves powder has water purification properties through flocculation. It also supplements the food in the human diet and in the fortification of livestock feed, especially in developing countries. So, M. oleifera properties have also been applied to cosmetic and byproducts industries due to the high nutritive and protective properties of its seed oil. According to the holistic or traditional medicine, M. oleifera has very relevant therapeutic properties and applications depending on the constitution, somatic and psychological needs of patients. It is usually referred as a natural product that can treat different physical and psychological health aspects, offering an energetic action and structural rebuilder of the body and promoting emotions of highly positive attitudes towards life. The high and specific immunological potential of $M$. oleifera leads us to suggest an in-depth study to assess the hypothesis of conferring a supportive effect against Covid-19 disease.
\end{abstract}

Keywords Moringa oleifera $\cdot$ Drumstick tree $\cdot$ Miracle tree $\cdot$ Medicinal plant $\cdot$ Cosmetics $\cdot$ Food supplement

\section{Introduction}

Moringa oleifera L. (Moringa pterygosperma G.), wellknown as the "drumstick" or "horseradish" tree, is native of Northwest India, its main producer, but can also be found in South Africa, Northeast Africa, Madagascar, Tropical Asia, Southwest Asia and Latin America. The Moringa genus comprises 14 species: $M$. arborea; $M$. longituba; $M$. borziana, M. pygmaea; M. hildebrandtii; $M$. drouhardii; M. longituba; $M$. peregrina; $M$. stenopetala; $M$. rivae; $M$. ruspoliana; M. Ovalifolia; M. Concanensis and M. oleífera (Rani et al. 2018). From the Moringaceae family, M. oleifera is the most known, studied and used species (Anwar 2005; Olson 2011) with human and animal applications. The various resources obtained from this plant-leaves, flowers, seeds, pods, bark and roots—can be used for cooking or in traditional medicine to treat several pathologies. M. oleifera has the capability to survive in humid or dry hot climates
4 CBSin, Center of BioSciences in Integrative Health, Porto, Portugal 
and poor soils (Anwar et al. 2007; Mainenti 2018). M. oleifera is a highly nutritious plant, being ideal to treat malnutrition in developing countries (Zongo 2013; Valdez-Solana et al. 2015; Gopalakrishnan 2016; Debajyoti et al. 2017). $M$. oleifera gained the title of "Miracle Tree" and commercial attention supported on several properties such as nutritional values, amino acids and flavonols content which can be used in food supplements and cosmetic industry (Tables 1, 2, 3 and 4). In fact, when compared to other plants, from $100 \mathrm{~g}$ of dry leafs of M. oleifera we can obtain 7 times more vitamin $\mathrm{C}$ than from oranges, 10 times more vitamin A than from carrots, 17 times more calcium than in milk, 9 times more protein than in yoghurt, 15 times more potassium than from bananas and 25 times more iron than the obtained from spinach (Oduro et al. 2008; Rockwood 2013; Saini et al. 2016). Table 1 shows the nutritional values for the edible parts of raw pods and leaves, obtained from the United States Department of Agriculture (USDA) database, although it is
Table 1 Nutritional values per $100 \mathrm{~g}$ of the edible portion of M. oleifera pods and leaves

\begin{tabular}{|c|c|c|c|}
\hline \multirow[t]{2}{*}{ Components } & \multicolumn{3}{|l|}{ Per $100 \mathrm{~g}$} \\
\hline & Raw pods ${ }^{\mathrm{a}}$ & Raw leaves ${ }^{\mathrm{a}}$ & Dried leaves $^{\mathrm{b}}$ \\
\hline Energy (kcal) & 37 & 64 & $304 \pm 87$ \\
\hline Water $(\mathrm{g})$ & 88.20 & 78.66 & $0.0074 \pm 0.0029$ \\
\hline Protein $(\mathrm{g})$ & 2.10 & 9.40 & $24 \pm 5.8$ \\
\hline Total lipid (g) & 0.20 & 1.40 & $6 \pm 2.5$ \\
\hline Carbohydrate, by difference (g) & 8.53 & 8.28 & $36 \pm 9.2$ \\
\hline Fibre, total dietary (g) & 3.2 & 2.0 & $20.6-28.6^{*}$ \\
\hline Fatty acids, total saturated (g) & 0.033 & - & - \\
\hline Fatty acids, total monounsaturated (g) & 0.102 & - & - \\
\hline Fatty acids, total polyunsaturated (g) & 0.003 & - & - \\
\hline Fatty acids, total trans (g) & 0.000 & 0.000 & - \\
\hline Cholesterol (mg) & 0 & 0 & - \\
\hline Vitamin A (RAE) $(\mu \mathrm{g})$ & 4 & 378 & $3639 \pm 1979.8$ \\
\hline Vitamin D (D2 + D3) $(\mu \mathrm{g})$ & 0.0 & 0 & - \\
\hline Vitamin D (IU) & 0 & 0 & - \\
\hline Thiamin (mg) & 0.053 & 0.257 & 2.6 \\
\hline Riboflavin (mg) & 0.074 & 0.660 & $1.29-20.5^{*}$ \\
\hline Niacin (mg) & 0.620 & 2.220 & 8.2 \\
\hline Pantothenic acid (mg) & 0.794 & 0.125 & - \\
\hline Vitamin B-6 (mg) & 0.120 & 1.200 & 2.4 \\
\hline Vitamin B-12 $(\mu \mathrm{g})$ & 0.00 & 0.00 & - \\
\hline Vitamin E (mg) & - & - & $56-113^{*}$ \\
\hline Vitamin $\mathrm{C}$, total ascorbic acid (mg) & 141.0 & 51.7 & $172 \pm 37.7$ \\
\hline Folate total $(\mu \mathrm{g})$ & 44 & 40 & 540 \\
\hline Folic acid $(\mu \mathrm{g})$ & 0 & 0 & - \\
\hline Sodium (mg) & 42 & 9 & $220 \pm 180.0$ \\
\hline Potassium (mg) & 461 & 337 & $1467 \pm 636.7$ \\
\hline Calcium (mg) & 30 & 185 & $1897 \pm 748.4$ \\
\hline Phosphorus (mg) & 50 & 112 & $297 \pm 149.0$ \\
\hline Magnesium (mg) & 45 & 42 & $473 \pm 429.4$ \\
\hline Iron (mg) & 0.36 & 4.00 & $32.5 \pm 10.78$ \\
\hline Zinc (mg) & 0.45 & 0.60 & $2.4 \pm 1.12$ \\
\hline Copper (mg) & 0.084 & 0.105 & $0.9 \pm 0.48$ \\
\hline Manganese (mg) & 0.259 & 1.063 & - \\
\hline Selenium $(\mu \mathrm{g})$ & 0.7 & 0.9 & - \\
\hline
\end{tabular}

${ }^{a}$ Information obtained from United States department of agriculture nutrient database (https://ndb.nal.usda. gov/ndb/foods) in June 2018

${ }^{\mathrm{b}}$ Average values and standard deviation published by Witt (2013)

*Only two values were found (Witt 2013) 
Table 2 Amino acids and flavonols per $100 \mathrm{~g}$ of the edible raw portion of $M$. oleifera leaves

\begin{tabular}{lc}
\hline & Per $100 \mathrm{~g}$ \\
Components & Raw leaves \\
\hline Amino acids & \\
Tryptophan (g) & 0.144 \\
Threonine (g) & 0.411 \\
Isoleucine (g) & 0.451 \\
Leucine (g) & 0.791 \\
Lysine (g) & 0.537 \\
Methionine (g) & 0.123 \\
Cystine (g) & 0.140 \\
Phenylalanine (g) & 0.487 \\
Tyrosine (g) & 0.347 \\
Valine (g) & 0.611 \\
Arginine (g) & 0.532 \\
Histidine (g) & 0.196 \\
Alanine (g) & 0.705 \\
Aspartic acid (g) & 0.920 \\
Glutamic acid (g) & 1.035 \\
Glycine (g) & 0.517 \\
Proline (g) & 0.451 \\
Serine (g) & 0.414 \\
Flavonols & \\
Isorhamnetin (mg) & 0.4 \\
Kaempferol (mg) & 6.0 \\
Myricetin (mg) & 0.0 \\
Quercetin (mg) & \\
\hline
\end{tabular}

Information obtained from United States department of agriculture nutrient database (https://ndb.nal.usda.gov/ndb/foods) in June 2018

known that the nutrient content varies according to the plantation site (Aslam 2005) and seasons (Witt 2013). The nutritional value of dried leaves, not existent in USDA database, is presented as an average of values with standard deviation calculated from diverse papers that was compiled and published by Witt (2013). From leaves to roots, it is possible to obtain good quantities of important minerals, proteins, vitamins, $\beta$-carotene, amino acids and phenolic compounds (Anwar et al. 2007; Leone et al. 2015a, b; Saini et al. 2016; Fahey 2005, 2017; Debajyoti et al. 2017; Divya et al. 2019). M. oleifera extracts have been studied with different medicinal purposes: anti-inflammatory, antihypertensive, diuretic, antimicrobial, antioxidant, antidiabetic, antihyperlipidemic, antineoplastic, antipyretic, antiulcer, and hepatoprotectant (Fahey 2005, 2017; Abdull Razis et al. 2014; Divya et al. 2019). Anwar et al. (2007) published a table with various traditional medicinal uses of the different parts of M. oleifera (Anwar et al. 2007). The attractive properties of this plant led to studies of side effects and medical interactions in animal models and humans.
According the revision by Stohs and Hartman (2015), until this date none of the human, in vitro studies, or extrapolations of animal studies to humans, reported adverse effects with doses of $M$. oleifera leaves and leaf extracts achievable by oral ingestion. Although, there was not any report of major adverse side effects, there are some important information that should be registered. In fact, there are some studies suggesting that M. Oleifera cannot be used in combination with other modern medicines in humans. A research by Gholap et al. (2004) concluded that M. oleifera has been noted to be a good regulator of insulin. Thus, according Sileshi et al. (2014), patients suffering from lack of insulin will probably have adverse reductions of sugar levels when using $M$. oleifera for medicinal purposes, suggesting that it could decrease the blood sugar to even lower levels when used in combination with other modern medications. Another study suggests that when treating thyroids, $M$. oleifera compounds of the leaf may improve thyroid function (Tahiliani et al. 2000), this well proving evidence further suggests that it can possibly conflict with other thyroid medication triggering drug interaction.

A research work concerning the "Acceptability and safety of short-term daily supplementation in a group of malnourished girls" assessed the use, acceptability and safety of M. oleifera on children (girls) in Zambia (Barichella et al. 2019). With regards to safety concerns, supplementation of $14 \mathrm{~g}$ per day of M. oleifera powder was deemed safe for children and adolescents both in the short and long term. This research also noted that mild nausea was reported in $20 \%$ of the children at various age groups when meals were supplemented with $20 \mathrm{~g}$ of $M$. oleifera daily showing to be still an inadequate and symptomatic dose in children.

Other studies suggest that $M$. oleifera could adverse and slowly breaking down the pharmaceutical drugs in the liver and thus, may develop cirrhosis and liver failure resulting in malnutrition and weight loss, as well as decreased cognitive function (Das et al. 2012; Kelly 2000; Sileshi et al. 2014).

Despite the numerous positive health benefits associated with $M$. oleifera phytochemicals, there are suspicions that it contains harmful substances (Fahey et al. 2001; Annongu et al. 2014; Maizuwo 2017). It contains specific chemical compounds, such as alkaloids and other phytotoxins, which when consumed in high doses presents potentially nerve-paralysing properties and other adverse effects (Maizuwo et al. 2017). Some of these phytochemicals include moringine, moringinine, estrogen, pectinesterase and phenols including tannin (Fahey et al. 2001). There are unconfirmed reports that $M$. oleifera stems, roots and flowers potentially contain harmful phytochemical constituents, especially during pregnancy, which may promote uterus contraction, leading to miscarriages in pregnant women (Dutta 2017). It is also suspected that it can prevent implantation in women, hence it must be avoided 
Table 3 Compilation of food supplements containing M. oleifera tree parts or extracts (in June 2018)

\begin{tabular}{|c|c|c|}
\hline Tree parts & Brand/Product & Product information \\
\hline & Naturinga & \\
\hline \multirow[t]{5}{*}{ Leaves } & Moringa capsules & $\begin{array}{l}\text { Regulates the gastrointestinal transit; natural anti-inflammatory; lowers cholesterol } \\
\text { levels; improves diabetic condition }\end{array}$ \\
\hline & Moringa tea & $\begin{array}{l}\text { Delays the ageing process; ensures proper digestion; high antioxidant power; helps } \\
\text { healing process; tonifies body and mind }\end{array}$ \\
\hline & Moringa kids multivitamin complex & $\begin{array}{l}\text { Strengthens the immune system; rich in vitamins and minerals; stimulates natural } \\
\text { defenses }\end{array}$ \\
\hline & Moringa powder & $\begin{array}{l}\text { Adds nutritional value; source of fiber, protein, vitamins and minerals; improves } \\
\text { physical condition }\end{array}$ \\
\hline & Bio-hera & \\
\hline \multirow{3}{*}{$\begin{array}{l}\text { Dried seeds extract } \\
\text { Leaves }\end{array}$} & Moringa capsules & Strengthens the immune system; helps to reverse the aging process; beautifies the \\
\hline & Moringa syrup & $\begin{array}{l}\text { skin; reduces the appearance of wrinkles and fine lines; maintains the normal } \\
\text { glucose level; stimulates brain function and concentration; increases libido }\end{array}$ \\
\hline & Miracle tree & \\
\hline \multirow[t]{5}{*}{ Leaves } & Moringa organic tea & It is a nutritionally complex whole food naturally rich in vitamins, minerals and \\
\hline & $\begin{array}{l}\text { Organic Moringa superfood supple- } \\
\text { ments-capsules }\end{array}$ & $\begin{array}{l}\text { amino acids. Daily use of Moringa can help to restore your imbalances in your } \\
\text { diet }\end{array}$ \\
\hline & Moringa Superfood Powder & \\
\hline & Moringa Superfood Sticks & \\
\hline & Iswari & \\
\hline \multirow[t]{2}{*}{ Leaves } & Moringa powder organic & $\begin{array}{l}\text { The Moringa leaf boasts a vast array of beneficial nutrients, making this tree one of } \\
\text { the highest plant sources of vitamins and minerals around }\end{array}$ \\
\hline & Drasanvi & \\
\hline Leaves, dry extract & Nutrabasics-Moringa & $\begin{array}{l}\text { The richness of its active ingredients helps maintain blood glucose levels. Provides } \\
\text { Flavonoids }(2.5 \%) \text { and Polyphenols }(5 \%)\end{array}$ \\
\hline
\end{tabular}

by those attempting to conceive as it functioning as an abortifacient (Nath et al. 1997; Dutta 2017). Finally, cytotoxicity was verified in experiments with human peripheral blood mononuclear cells only at $20 \mathrm{mg} / \mathrm{kg}$ of an aqueous leaf extract; genotoxicity on blood rat's cells was verified at $3000 \mathrm{mg} / \mathrm{kg}$ (Asare et al. 2012). However, all mentioned side effects were verified with doses that far exceed the amounts used in food intake (Asare et al. 2012).

So, research on the adverse side effects with doses achievable by oral ingestion should still go on, since currently there are no scientifically confirmed clear toxic and harmful effects of $M$. oleifera extracts and products on both human and animal models (Adedapo et al. 2009; Stohs et al. 2015).

Many studies on nutrition, phytotherapy disease treatment and prevention goals have been published, thus supporting scientific basis about the efficiency of traditional uses of M. oleifera (Fahey 2005, 2017). In fact, records about symptoms, signs and treatment strategies in different diseases are found in several ancient texts of traditional medicines such as Ayurveda and Traditional Chinese Medicine (TCM) (Karadi et al. 2006; Kasote et al. 2017; Debajyoti et al. 2017). As an endemic source with highly digestible protein, $\mathrm{Ca}, \mathrm{Fe}$, Vitamin $\mathrm{C}$, and carotenoids is considered as a suitable natural product to be used by undernourishment populations (Dixit 2016).

\section{The resources obtained from $M$. oleifera tree on a conventional approach}

\section{Leaves and pods}

In some countries, leaves and fruits are commonly used in culinary as vegetables. Leaves can also be dried and used in infusions or grounded into powder, allowing easier conservation and consumption (Moyo 2011; Olson et al. 2016). In all ways of use and conservation, $M$. oleifera does not lose nutritional value (Mahmood 2010). Leaves and pods are low in calories and rich in minerals, vitamins and natural antioxidants (Table 1) (Anwar 2005; Rebufa et al. 2018). Phytochemicals like flavonoids are also present in leaves as well as a significant percentage of essential amino acids (Table 2). M. oleifera leaves contain a high quantity of polyunsaturated fatty acids and low saturated fatty acids content (Moyo 2011), which combined with diuretic, lipid and blood pressure lowering properties from leaves and pods, contribute to the maintenance 
Table 4 Compilation of cosmetics containing M. oleifera tree parts or extracts as ingredients (in June, 2018)

\begin{tabular}{|c|c|c|}
\hline Cosmetic ingredients & Product brand/name & Product information \\
\hline & SkinSecret & \\
\hline \multirow[t]{5}{*}{ Leaves } & Anti-wrinkle face cream & Purifying and protective action against environmen \\
\hline & Anti-aging moisturizer face cream & tal stress, such as smoke and pollution \\
\hline & Hand cream & \\
\hline & Body milk & \\
\hline & Lush & \\
\hline \multirow[t]{5}{*}{ M. pterygosperma oil } & African paradise (body conditioner) & Moisturizing, nourishing \\
\hline & Queen bee (hair honey) & \\
\hline & Magical Moringa (facial moisturizer) & \\
\hline & Charity pot (Hand and body lotion) & \\
\hline & Passion fruit (lip balm) & \\
\hline M. pterygosperma leaf infusion/oil & Go faster feet (foot lotion) & \\
\hline \multirow[t]{3}{*}{ M. pterygosperma powder } & Twinkle toes (foot powder) & Deodorizing \\
\hline & Lush gardener (cold pressed soap) & Remove dirt, moisturizing, nourishing \\
\hline & Laboratoires Sérobiologiques & \\
\hline \multirow[t]{2}{*}{$\begin{array}{l}\text { Active ingredient: peptide from Moringa } \\
\text { seeds }\end{array}$} & PURISOFT $^{\circledR}$ & $\begin{array}{l}\text { Skin cleansing/purification; protects skin against } \\
\text { pollution, heavy metals, cigarette smoke }\end{array}$ \\
\hline & Body shop & \\
\hline M. pterygosperma oil & $\begin{array}{l}\text { Moringa range (shower gel, oil, body butter, } \\
\text { body milk, body sorbet, hand cream, soap, } \\
\text { body scrub) }\end{array}$ & Skin feels smooth and restored \\
\hline \multirow[t]{2}{*}{ M. oleifera leaf extract } & Moringa eau de toilette Moringa body mist & $\begin{array}{l}\text { Delicately scent your skin in a crisp, floral aroma } \\
\text { with Moringa }\end{array}$ \\
\hline & Clarins & \\
\hline \multirow[t]{7}{*}{ M. pterygosperma seed extract } & Extra-comfort anti-pollution cleansing cream & $\begin{array}{l}\text { Eliminates traces of pollution, detoxifies the epider- } \\
\text { mis and protects the skin from the harmful effects } \\
\text { of pollution }\end{array}$ \\
\hline & One-step facial cleanser & $\begin{array}{l}\text { Neutralizes the effects of pollution and purifies the } \\
\text { skin to restore its natural radiance }\end{array}$ \\
\hline & Exfoliating body scrub & Purifies and refines while preserving your skin's \\
\hline & One-step gentle exfoliating cleanser & natural moisture balance. Neutralizes the harmful \\
\hline & Water purify/comfort one-step cleanser & \\
\hline & Daily energizer cleansing gel & \\
\hline & Naturinga & \\
\hline \multirow[t]{3}{*}{ M. oleifera seeds and oil } & Moringa soap bio & $\begin{array}{l}\text { High antioxidant value slowing skin ageing; exfoli- } \\
\text { ate dead cells by regenerating the tissue }\end{array}$ \\
\hline & Moringa exfoliating face scrub & $\begin{array}{l}\text { Moringa seeds peel and exfoliate the skin, while } \\
\text { Moringa oil moisturizes and regenerates the skin }\end{array}$ \\
\hline & Moringa $\mathrm{O}^{2}$ & \\
\hline \multirow[t]{3}{*}{ M. oleifera leaf extract/oil } & Herbal moisturizing lotion/facial toner/soap & Rejuvenate, nourish and protects skin \\
\hline & herbal shampoo/conditioner & Repairs, strengthens, reduces hair fall \\
\hline & Shu Uemura & \\
\hline M. pterygosperma seed extract & $\begin{array}{l}\text { Anti-Oxi + pollutant and dullness clarifying } \\
\text { cleansing oil }\end{array}$ & $\begin{array}{l}\text { Enhanced power to remove micro impurities and } \\
\text { stubborn make-up; anti-pollution breakthrough }\end{array}$ \\
\hline M. pterygosperma extract & $\begin{array}{l}\text { Urban moisture hydro-nourishing shampoo/ } \\
\text { conditioner/double serum/deep treatment } \\
\text { masque }\end{array}$ & $\begin{array}{l}\text { Highly concentrated in nutrients, vitamins and anti- } \\
\text { oxidants intensely hydrates deep within strands }\end{array}$ \\
\hline
\end{tabular}


Table 4 (continued)

\begin{tabular}{lll}
\hline Cosmetic ingredients & Product brand/name & Product information \\
\hline M. oleifera seed extract & $\begin{array}{l}\text { Bio-Beauté } \\
\text { Anti-pollution micellar cleansing water/gen- } \\
\text { tle cleansing foam/cleansing oil gel/gentle } \\
\text { exfoliating gel } \\
\text { Dual-phase waterproof eye make-up remover }\end{array}$ & $\begin{array}{l}\text { Removes makeup, pollution particles and excess } \\
\text { sebum, while leaving the skin well moisturized. } \\
\text { The Seed of Moringa extract selected contains } \\
\text { purifying peptides which, on the surface, limit } \\
\text { the adhesion of the pollution particles and, in } \\
\text { depth, activate their elimination. This extract acts } \\
\text { as a protective shield capable of preserving the } \\
\text { good bacteria from the cutaneous flora against the } \\
\text { aggression of pollution }\end{array}$ \\
&
\end{tabular}

of cardiovascular health (Anwar et al. 2007) (Table 5). In dried $M$. oleifera leaves, it was also found a high content in calcium and iron, which is normally residual in other plants used in our diet. In the leaves is found greater a variety and quantity of proteins, when comparing to other tree parts (Rebufa et al. 2018; Wang et al. 2016). Due to its nutritional rich values, $M$. oleifera can be a good enriching food additive to human diet and also an animal feed fortifier (Moyo 2011). Adding fresh or dried leaves to the feed of milk cows increased milk production (43 and $65 \%$ respectively), that fact would be of great importance in developing countries to fight deficiencies in nutrition (Bhargave 2015). Studies of acceptance by the consumer of enriched foods/snacks with $M$. oleifera have been obtaining good results (Ellis 2011; Jung 2016). M. oleifera can also help lactating mothers produce more milk and help to treat malnutrition in young children. Phytosterols from $M$. oleifera increase estrogen production that enhance the activity of the mammary glands ducts (Gopalakrishnan 2016). Doses of $0.042 \mathrm{mg} / \mathrm{g}$ of body weight given to mice result in increased milk production. Also, the pup weight augment with increasing doses of M. oleifera leaf powder intake (Titi et al. 2013; Titi and Nurjanah 2014). Studies of toxicity in animals show that $M$. oleifera dried leaf extract might be safe for consumption, although in high doses and prolonged intakes, $M$. oleifera may cause toxicity by accumulation of some elements (Ali et al. 2019). The amount of $70 \mathrm{~g}$ of $M$. oleifera dried leaf per day is the maximum recommended doseage (Asiedu-Gyekye et al. 2014). Table 3 compiles some food supplements based on $M$. oleifera tree parts or extracts. A hydroalcoholic extract of green pods increased liver enzymes involved in the detoxification of xenobiotic substances in mice (Table 5), suggesting a chemo preventive potential of a drumstick extract against chemical carcinogenesis (Bharali et al. 2003). $M$. oleifera pods are also valuable to treat digestive and obesity problems and thwart colon cancer (Gopalakrishnan et al. 2016). $\beta$-carotene, the major component reported from the drumsticks of the $M$. oleifera plant as well as the presence of vitamin A and C suggest an action in the induction of antioxidant and anti-inflammatory profiles (Geervani and Devi 1981; Bharali et al. 2003; Praengam et al. 2014). It was suggested that $\beta$-carotene and sterols present in the plant pods acts as potent inhibitors on the formation of reactive oxygen intermediates, a pre-requisite for tumorigenesis and so inducing apoptosis in the mouse colon carcinoma model (Gupta et al. 2010; Kraiphet et al. 2018).

Studies in rats showed that $M$. oleifera leaves extract might act as potential neuroprotectant via decreased oxidative stress and the enhanced cholinergic function (Kirisattayakul et al. 2013) and function as a cognitive enhancer, hence being used in dementia cases (Sutalangka et al. 2013). It was also found an anti-depressant activity in mouse models of depression when giving orally a $200 \mathrm{mg} / \mathrm{kg} /$ day of a $M$. oleifera alcoholic extract plus $10 \mathrm{mg} / \mathrm{kg} /$ day fluoxetine, for 14 days (Kaur et al. 2015). This effect can be increased when combined with fluoxetine (as a selective serotonin reuptake inhibitor-SSRI) according to Sutalangka et al. (2013) and Kaur et al. (2015). The influence of M. oleifera may be due to the action of antioxidants and flavonoids through radical scavenging, since its action is verified in other studies on animal models with cerebrovascular diseases exerting a multiplicity of neuroprotective actions within the brain and suppressing neuro-inflammation and thus suggesting a great potential to promote memory, learning and cognitive function (Vauzour et al. 2008).

Other studies with consumption of M. oleifera leaf powder revealed properties in human an animal models such as decreased blood glucose levels on diabetic type two subjects (William 1993), reduction on post prandial blood glucose (Ghiridhari 2011), increased insulin secretion in healthy subjects (Anthanont et al. 2016), decreased total plasma cholesterol and increased HDL (Nambiar 2010). The presence of $\beta$-sitosterol in $M$. oleifera leaves may be one of the reasons for decreasing plasma cholesterol since phytosterols cause less intestinal absorption of dietary cholesterol and increase its excretion on feces (Jain 2010; Mbikay 2012). 


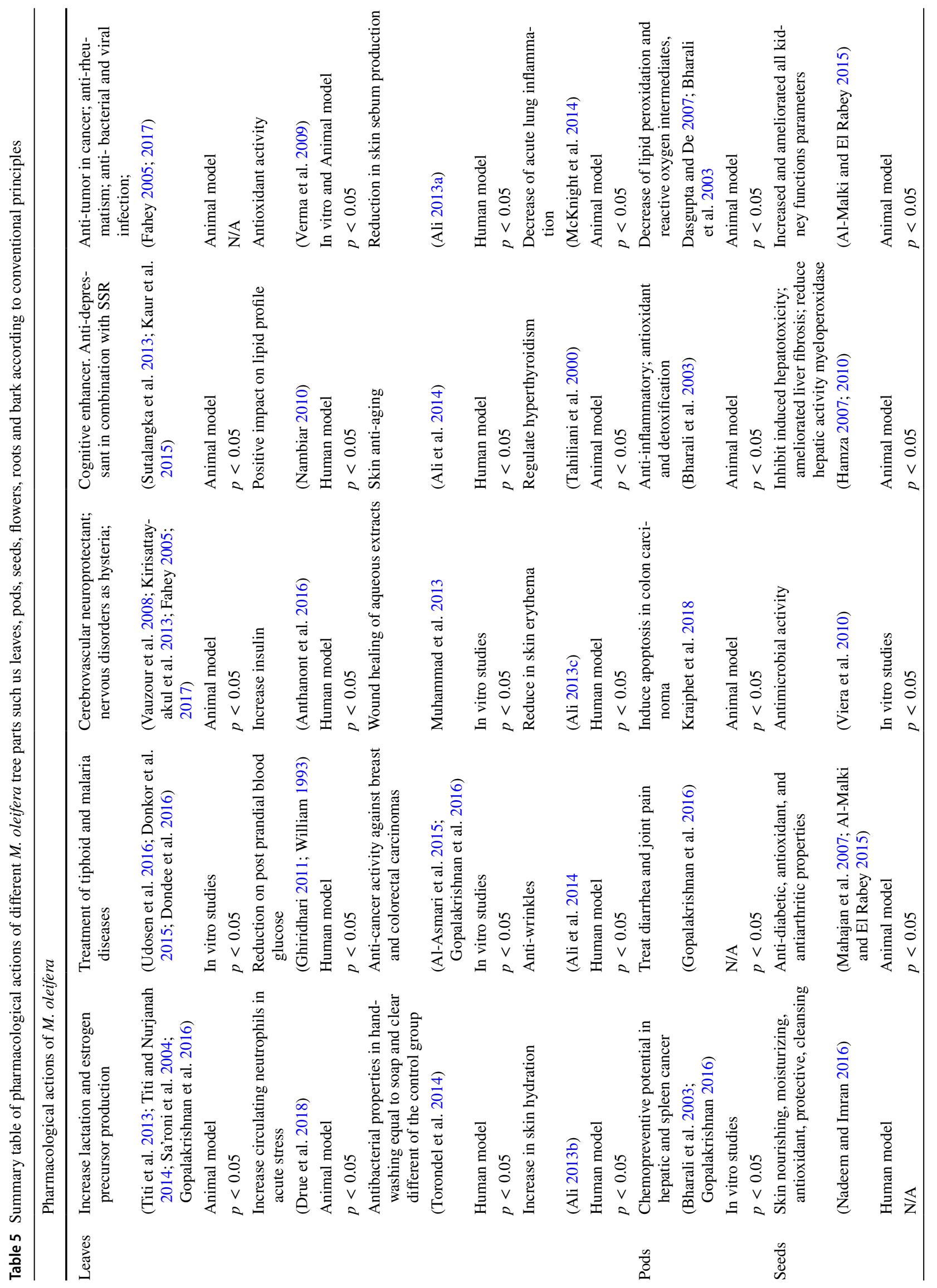




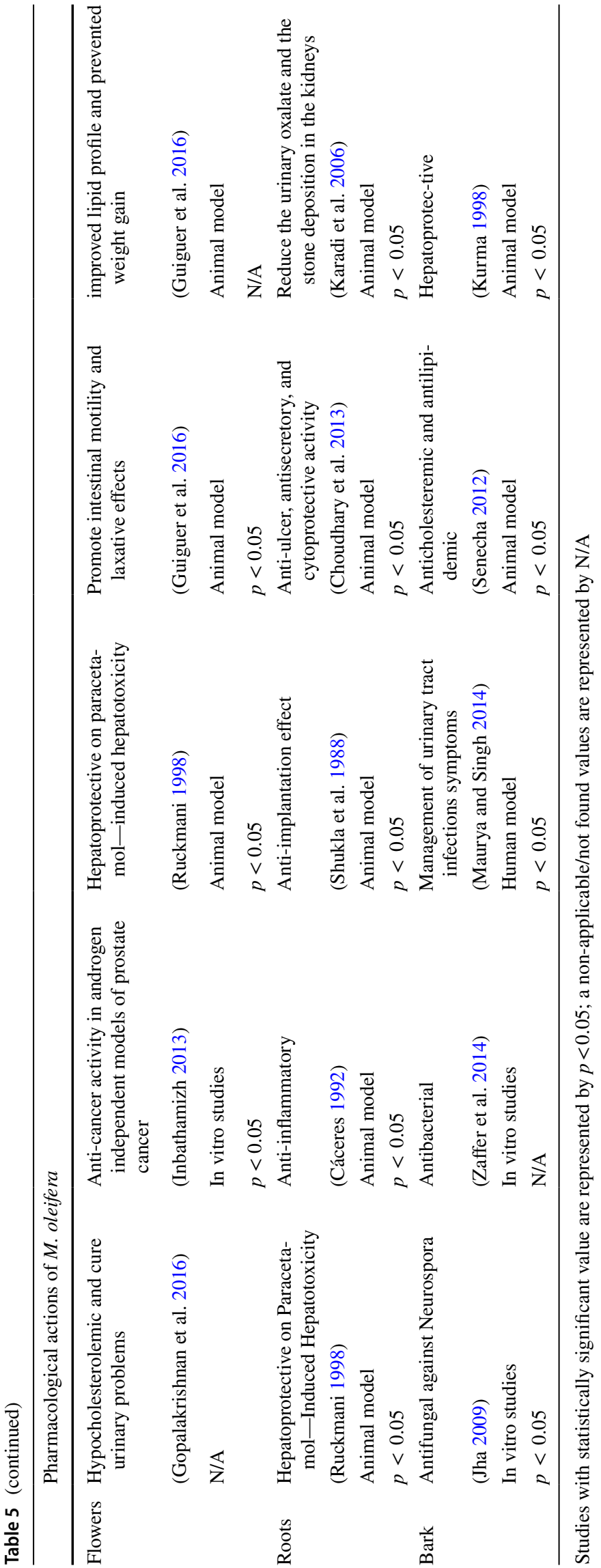

Several M. oleifera studies with leaf powder or extracts on animals revealed other properties beyond the previously referred: antioxidant, chemoprotectant and antihypertensive (Stohs and Hartman 2015). The antioxidant activity derives from the high amounts of polyphenols (Leone et al. 2015a, b; Verma et al. 2009). Leaves extracts have revealed anti-cancer properties with anti-neoproliferative activity by inducing Reactive Oxygen Species ROS production only in cancer cells which leads to cell apoptosis (Gopalakrishnan 2016). The active compounds present in extracts from leaves and bark revealed anti-cancer activity against breast and colorectal cancer cell lines through diverse mechanisms as decreased cell mobility, decreased colony formation, low cell survival, high apoptosis and G2/M enrichment (AlAsmari et al. 2015). Some extract fractions with anticancer activity have already been isolated, characterized and tested in vitro and in vivo (rat model) (Krishnamurthy et al. 2015) (Table 5).

In traditional medicine, a paste made of leaves is applied externally in wounds (Siddhuraju and Becker 2003). Some scientific studies have shown that leave extracts have beneficial properties in skin. Aqueous leaves extract increased human dermal fibroblasts proliferation leading to faster wound healing (Muhammad et al. 2013). A M. oleifera leave extract fraction with ethyl acetate, in low concentration $(12.5-50 \mu \mathrm{g} / \mathrm{ml})$, showed in vitro effect in skin healing by increasing proliferation of human dermal fibroblasts (Gothai et al. 2016). A hydroalcoholic extract of M. oleifera leaves used in a cream showed antiaging characteristics due to phenolic compounds. Sunscreen and photo protective characteristics were studied very recently (Baldisserotto et al. 2018). When applying a cream with this extract it was also verified a reduction in sebum production (Ali et al. 2013a, b, c) (1), and in transepidermal water loss allowing to increase hydration (Ali et al. 2013a, b, c) (2). Wrinkles and other signs of lack of skin vitality where improved during 3 months of using the same topic formulation with $M$. oleifera leaf extract (Ali et al. 2014). The compounds responsible for this improvement in skin surface appear to be phenolics (e.g., kaempferol and quercetin) and antioxidants such as vitamins A, C and B (Jadoon et al. 2015). M. oleifera leaf extract cream was also tested for potential skin irritation by a $48 \mathrm{~h}$ semi-occluded patch test and proved to be non-irritant and well accepted by the volunteers, also reducing skin erythema (Ali et al. 2013a, b, c) (3) (Table 5). M. oleifera leaf powder can be used to clean hands when four grams of wet (more efficient) or dried powder are applied on hands and rubbed (Torondel et al. 2014). The efficacy results were the same as for non-medicated soap, revealing potential to help in hand hygiene and prevent pathogen transmission in developing countries, where hygiene products are scarce.

A leave extract sprayed in plant crops revealed another utility for this plant, having beneficial effects on the growing 
rate, size and resistance on those plants and fruits (Bhargave 2015). M. oleifera leaf tea studies demonstrated alterations in blood circulating neutrophils and conclude that Moringa tea has adaptogenic capabilities in cases of stress (Drue et al. 2018) (Table 5). Previous studies using dried Moringa leaves tea in mouse model with acute lung inflammation, showed that mice that had decreased lung inflammation marked by alterations in cytokine production, leukocyte migration, and neutrophil apoptosis (McKnight et al. 2014). An ethanolic extract of Moringa leaves has anti-anxiety effect in swiss albino mice, the ethanolic extract of M. oleifera leaves may have produced its anxiolytic effects via multiple mechanisms (Bhat 2014).

\section{Seeds}

Seeds, collected from pods, can be eaten raw or cooked. From M. oleifera seeds, a rich vegetable oil can be produced. M. oleifera seed oil or Behen/Ben oil is produced through the cold pressing of the M. oleifera seeds. M. oleifera oil can be used to cook, as a source to prepare biodiesel, as a lubricant and in the cosmetic industry (Rashid et al. 2008). The oil name comes from its high content on behenic acid, which confers more resistance to oxidative degradation comparing to other vegetable oils. Ben oil is rich in oleic acid (up to 76\%), palmitic (6.54\%), but also stearic (6\%), behenic (7\%), and arachidic (4\%) (Anwar 2005). It is used in various cosmetic formulations as emollient and confers nourishing, moisturizing, antioxidant and protective properties. It is also a good skin cleansing product (Nadeem and Imran 2016). Table 4 details some cosmetic brands that use $M$. oleifera leaves, oil or active extracts as ingredients in the composition of their products. This oil is also used in the enfleurage process, allowing the extraction of fragrances and active compounds from difficult sources as flower petals. Milled M. oleifera seed shells can be used as a natural exfoliating agent.

Moringa oleifera seeds can also help diabetic patients (Table 5). Some studies by Al-Malki and El Rabey (2015) showed its anti-diabetic activity by reducing the blood glucose level when rats where treated with 50 or $100 \mathrm{mg}$ of $M$. oleifera seeds powder $/ \mathrm{kg}$ body weight, during 4 weeks. At the same time, ingestion lead to an increase in antioxidant enzymes and consequently the compound content such as glucomoringin, phenols, and flavonoids. Moreover, the same authors, treating these diabetic rats significantly increased and ameliorated all kidney functions parameters. In fact, $M$. Oleifera seeds ameliorated liver fibrosis in rats reducing liver damage and symptoms of liver fibrosis, decrease the CCl4-induced elevation of serum aminotransferase activities and globulin level as well as reduce the elevated hepatic hydroxyproline content and myeloperoxidase activity
(Hamza 2010) improving the indices of hepatoxicity in rats, such as malonialdehyde level and total antioxidant capacity, glutathione content, catalase, and superoxide dismutase activities (Hamza 2007).

Treatment with $M$. oleifera seeds also altered oxidative stress in relation to its anti-inflammatory activity. Histopathological observations showed mild or less infiltration of lymphocytes, angiogenesis and synovial lining thickening. From all above results and observations, it can be concluded that the seeds possess promising antiarthritic property (Mahajan et al. 2007).

These seeds have others appeals to the daily life and industry. Seed powder showed capacity to purify water and remove heavy metals and organic compounds (Sharma et al. 2006) through low molecular weight cationic proteins mediated precipitation (Kansal and Kumari 2014). There was a reduction of $80-99.5 \%$ in the turbidity of the water and $90-99.99 \%$ of bacterial reduction (Bhargave 2015; Lea 2014). The remaining paste after the oil extraction still has the same flocculation properties, serving both purposes and adding value (Lea 2010). Compounds such as pterygospermin, moringine and benzyl isothiocyanate isolated from M. oleifera seeds showed antimicrobial effect (Viera et al. 2010). Accordingly, there is applicability for M. oleifera seeds in the prevention of microbial diseases (Table 5). $M$. oleifera oil has also been tested for its potential to produce biodiesel, contributing as an alternative to the conventional diesel fuel (Rashid et al. 2008).

\section{Flowers and roots}

M. oleifera flowers are used directly as part of the diet, but also to make infusions which have hypocholesterolemic properties (Gopalakrishnan 2016) (Table 5). The flowers can also be a source of nectar and are used to produce honey (Gopalakrishnan 2016). A methanol extract of $M$. oleifera flowers revealed anti-cancer properties by inhibiting growth of PC3 cells (androgen-independent model of prostate cancer) in a dose-dependent manner, while not affecting the viability of normal cells (Inbathamizh 2013). According general evaluation by Fahey (2005, 2017) and (Divya et al. (2019), also supporting on several researches (e.g., Delaveau Boiteau 1980; Hameed et al. 1998; Faizi et al. 1998; Fuglie 1999) it is possible to attribute several relevant effects based on the M. oleifera flower treatments which consist in: general disorders as tonic and anti- catarrh; antimicrobial-bacterial and viral Infection; against helminths parasites, external sores, ulcers and fever; nervous disorders as hysteria; anti-tumor in cancer therapy; diuretic in endocrine and circulatory disorders; anti-rheumatism in inflammation processes. So, it could be added to industrial products in order to provide healthier products to the consumers (Guiger et al. 2016; 
Gopalakrishnan et al. 2016). M. oleifera roots and flowers extracts revealed hepatoprotective effect on rat paracetamol-induced hepatotoxicity (Ruckmani 1998). Roots also showed antiinflamatory effect on animal model of induced hind paw edema and antimicrobial activity (Cáceres 1992; Ruckmani 1998). An aqueous extract of M. oleifera roots when given orally to rats, in a dose-dependent manner, influenced the hormone balance necessary to gestation, leading to an anti-implantation effect (Shukla et al. 1988). A study with an ethanolic root bark extract showed antiulcer, antisecretory (reducing gastric acid secretion), and cytoprotective action in rats with gastric ulceration (Table 5). The extract dosage of $500 \mathrm{mg} / \mathrm{kg}$ showed the highest protection in the both ulcer models studied (ethanol-induced and pylorus ligation-induced gastric ulceration) (Choudhary et al. 2013). The alkaloids (moringine, moringinine), saponins, triterpenoids and tannins present in M. oleifera appear to be the plant compounds with antiulcer activity and conferring protective capacity through diverse mechanisms (Choudhary et al. 2013). Anti-inflammatory action was also verified by a methanol extract of M. oleifera roots in rat paw edema models (Ezeamuzie et al. 1996) (Table 5). Moringa root wood reduced the elevated urinary oxalate and lowered the deposition of stone forming constituents in the kidneys of calculogenic rats as a result of ethylene glycol treatment (Karadi et al. 2006).

\section{Bark}

The bark also has antimicrobial properties (Table 5). Root bark extracts by ethanol, methanol and distilled water showed antifungal activity against Neurospora crassa and Aspergilus niger, in which the higher the concentration, the higher mycelial inhibition, with a duration up to $96 \mathrm{~h}$ (Jha 2009). Antibacterial activity was also verified in a study with methanol, chloroform, ethyl actetate and water bark extracts. Staphylococcus aureus, Citrobacter freundii, Bacillus megaterium and Pseudomonas fluorescens growth was inhibited by all extracts in different concentrations and in different degrees (Zaffer et al. 2014). The presence of flocculating proteins of bark and roots might be part of the antimicrobial mechanism (Wang et al. 2016). A clinical study with 30 patients proved that $40 \mathrm{~mL}$ of stem bark decoction, twice a day, was effective in treating symptoms of urinary tract infection. (Maurya and Singh 2014). However, studies with larger samples are needed to access the viability of $M$. oleifera use in this and other pathologies. Hepatoprotective effect (Kurma 1998), anticholesteremic and antilipidemic activity (Senecha 2012) was also verified in rat model with different extracts of M. oleifera bark (Table 5).

\section{Therapeutic considerations based on traditional Asian medicines}

\section{Traditional ayurvedic medicine}

In terms of medicinal value, India's traditional ancient Ayurvedic Medicine has identified more than 300 diseases that could be cured with the different parts of M. oleifera, such as leaves, roots, bark, flowers and seeds. In order to better understand the traditional therapeutic effects of M. oleifera, according to the principles of Ayurvedic Medicine, we have to consider two main constitutional conditions for individuals, the Vata and Kafta constitution (Miller 1998; Ninivaggi 2010). Vata constitution embodies the energy of movement and is therefore often associated with wind and the air element. Vata is represented by the movement in the body, and manifests itself as the movement of nerve electric impulses, air, blood, food, waste and thoughts. Vata is linked to creativity and flexibility; it governs all movements and when unbalanced can lead to both physical and energetic exhaustion, causing all sorts of abnormal movements in the body, such as tics, tremors, and muscle spasms. Vata has seven characteristics, which are: cold, light, irregular, mobile, rarefied, dry, and rough. These qualities characterize their effect on the body. When there is excess of Vata, force can cause nerve irritation, high blood pressure, gas and confusion. Deficiency of Vata, causes congestion, constipation and thoughtlessness (Miller 1998).

Kapha constitution is related with solidity and structural cohesiveness of all things that holds things together, and is mainly associated with the earth and water elements. At one level, Kapha is represented by the cells which make up our organs and the fluids which nourish and protect them. Emotionally Kapha embodies the energies of love and compassion, which are related to water element. When out of balance, kapha have the tendency to create physically stagnation and congestion in organs and tissues in the body, including at the mind level. Excess of Kapha causes the tendency to produce mucous and obstruction in the sinus and nasal passages, the lungs and colon. At the level of the mind it creates rigidity, a fixation of thought, inflexibility. Deficiency of Kapha causes the body to experience a dry respiratory tract, burning stomach sensation (due to lack of mucous in the wall of stomach that gives protection from excess hydrochloric acid), and inability to concentrate the mind. Kapha force is described according to the following qualities: oily, heavy, stable, dense and smooth (Miller 1998; Ninivaggi 2010).

\section{The somatic properties of $M$. oleifera}

According to the Traditional Ayurvedic Medicine, the somatic properties and uses of the different parts of M. oleifera is expected to have several and specific effects depending 
on the somatic expression of patient, and its energetic Vata or Kapha constitution. The energetic and pharmacological actions as well as clinical uses, roots, barks, leaves and seeds are described in Table 6 and below:

Root Bitter, acrid, thermogenic, digestive, carminative, anthelmintic, constipating, anodyne, anti-inflammatory, emmenagogue, sudorific, diuretic, ophthalmic, rubefacient, expectorant, hematinic, antilithic, alexipharmic, stimulant and vesicant. They are useful to equilibrate the unbalance physical conditions of vata and kaphta constitutions with manifestations of dyspepsia, anorexia, verminosis, diarrhea, colic, flatulence, otalgia, paralysis, inflammations, amenorrhea, dysmenorrhea, fever, strangury, vesical and renal calculi, ascites, ophthalmopathy, cough, asthma, cardiopathy, abscess and pharyngodynia (Warrier 2010).

Bark Acrid, bitter, thermogenic, abortifacient, antifungal, cardiac and circulatory stimulant. It is useful in ascites, vitiated conditions of vata and kapha and ringworm.

Leaves Bitter taste, cold nature, anti-inflammatory, anodyne, anthelmintic, ophthalmic and rich in vitamins A and C. They are useful in scurvy, vitiated conditions of kapha and vata, wounds, tumors, inflammations and helminthiasis.

Seeds Acrid and bitter taste, cold nature, anodyne, antiinflammatory, purgative, antipyretic and ophthalmic. They are useful in neuralgia, inflammations, intermittent fevers and ophthalmopathy (Warrier 2010).

\section{The psychological and spiritual properties of M. oleifera}

Concerning Ayurvedic ancient texts, is mentioned the psychological and spiritual properties of M. oleifera, which is described as powerful herb that penetrates the deep layers of body's tissues and particularly into the bone marrow, which is the deepest tissues of all. Moringa oleifera has a powerful action in purifying the blood, removing impurities, toxins, parasites and metabolic wastes, helping to rejuvenate cells.

Moringa oleifera acts and influences at mental, emotional, energetic and spiritual level altogether, having a strong effect in the personality.

In terms of influencing the mind, M. oleifera was tested by scientific research, which proved to have anti-depressive and anxiolytic effects (Kaur et al. 2015), as well considered an adaptogenic and anti-stress herb (Drue 2018).

Leaves The leaves remarkable nutritional properties, are said to restore self-confidence and address indecisiveness. Ancient ayurvedic physicians also used the leaves to bring clarity and restore the body at deep levels, which both contribute to a feeling of certainty, courage and fearless.

Root The roots of the plant are said to be mildly calming and grounding, as is often the case with root medicines. The root is known to enhance feelings of serenity and balance as well as helping to keep one centered in times of change or uncertainty.
Seeds The seeds of the plant were used as a remedy for depression in ancient India, referred for their ability to give energy and overcome feelings of hopelessness. The seeds were considered tonifying and were believed to renew the spirit and reinvigorate the body, as well as the mind and emotions (Warrier 2010).

Flowers The flowers were believed to be beneficial and effective for helping to let go of traumatic memories that obstructed the mind, guilt, emotional wounds and phobias. M. oleifera flowers are said to encourage positive thinking and to renew the view on life, bringing light to the spirit (Warrier 2010).

\section{Traditional Chinese medicine-TCM}

Moringa oleifera is a native plant in the Himalayas and is found in the Chinese herbal medicine dictionary in China, although it is not noted in the TCM classical herbal books, and it's not considered a commonly used Chinese herb. However, a variant with wingless seeds has been collected in S Yunnan (Xishuangbanna Dai Zu Zizhizhou). In China, M. Oleiferae was introduced from India in the 1960s and had been cultivated on a large scale for ornament and distributed in southern provinces such us Guangdong, Taiwan and Yunnan, where is known as =lamu 辣木 (Mandarin) (Chen1998; Wan 2001; Zhang and Hengshan 2001).

Although, the nutritional value is important, according to the TCM principles it gives more importance to temperature and taste properties of herbs or food in order to determine if it is suitable for an individual with a certain temperature and constitutional tendency (Ross 2003).The most consumed part of M. oleifera are the leaves which present bitter and sweet taste, have a descending effect or downward movement and cooling property (Dong et al. 2019). Since $M$. oleifera leaves has cooling properties, it may not be suitable for everyone, especially to those persons who are cold constitution or yang deficiency, that normally are feeling cold, less active, tired, and other symptoms belonging to cold syndrome diseases.

Based on TCM concepts, Jing, which is translated as our bodies 'vital essence' or 'deep life force', is strongly related to bone marrow, and so being the marrow a manifestation of Jing essence in the body (Ross 2003). Moringa oleifera leaves, as demonstrated by their ability to reverse severe malnutrition, is a potent rebuilder of marrow in the body, essentially restoring life force energy at an extraordinarily deep level (Gopalakrishnan, 2016), influencing the behavior and mental level with positive mood, by giving will power, energetic and cheerful attitude towards life.

According to traditional Chinese medicine (TCM) principles different parts of the Moringa tree have different energetic functions (Table 7): 
Seeds and fruit Tonify the Spleen and eliminate dampness. Recommended for people with low appetite, bloating, heavy sensation in the limbs (Brown 2002). An oil is extracted from the seeds, which also contain a powerful flocculant that can be used to clarify turbid water.

Root The root has an acrid and pungent taste and warm nature, like the leaves and young fruits, are used for food.

Root and bark The root and bark eliminate wind, strengthen the stomach and spleen, support Yang and promote urination. It is recommended for headaches, dizziness, gastrointestinal problems, flatulence, high blood pressure, skin problems. (Brown 2002).

Leaves This most used part has an ability for reversing severe malnutrition eliminating dampness and heat as well as expelling toxins. It is recommended for gynecological problems such as vaginitis, excess discharge. It is also rich in iron, hence it can be used for anemic to tonify the blood (Brown 2002). According to the scientific research suggestions (Dong et al. 2019) and combined with the taste theory of TCM, we can speculated that M. oleifera leaves have cold property, sweet and bitter taste, redirected to the liver, spleen and/or stomach meridians.

In general, M. oleifera leaves according to TCM view, nourishes the earth element that is related to the spleen and stomach. Energetically is responsible in producing blood, directly linked to thoughts mechanism and mind activity. It works in the body as an astringent way by maintaining the blood in the vessels, governing the muscles, and act in the memory level (Liu 2003; Ross 2003). The main organ of Earth element is the spleen, and its responsible to remove the Gu Qi (Pure Energy) of the foods and send it to other organs to produce other pure substances like the Wei Qi (Defensive Energy) related to the immune system, Xue (Blood), and normal Qi (Energy) that circulates in the body meridians (Botsaris 2002; Ross 2003). The regular intake of M. oleifera can greatly benefit this important energetic organ in TCM, contributing for great performance of earth element in the body.

Cold nature-Analyzing deeply the energetic categorization of M. oleifera according to TCM principles, it can be said that, natural compounds presenting an inhibition role on the body's metabolism, are generally considered to have cold nature, while inflammation, high blood pressure, diabetes, constipation, etc. are also considered to be mainly Yang and belong to excess syndrome diseases. Moringa oleifera leaf, it is also considered to be anti-inflammatory, antihypertensive, hypoglycemic, laxative and other functions effect as well, leading Dong et al. (2019) to infer that M. oleifera leaf is cold. According to the study of phytochemical properties and its compatibility analysis, $M$. oleifera leaves are rich in alkaloids and has anti-inflammatory effects which confer similar nature as cold medicinal plants (Liwu et al. 2002; Leone et al. 2015). Additionally, the research study in $M$. oleifera based on analysis and comparison of trace elements, as calcium, sodium, potassium, phosphorus, magnesium, manganese, copper, iron, zinc and selenium in order to categorize under cold or hot nature TCM concept (Ronglin and Qiuxiu 1995; Olson et al. 2016), also shows that M. oleifera has strong evidence as cold medicinal plant.

Bitter or sweet taste-Curiously, most of the medicinal plants with cold nature present bitter taste, with pharmacological actions of antipyretic, antibacterial, antiviral, etc. effects (Ali et al. 2018). Currently, there are no deep studies on the taste of M. oleifera leaves but, it is believed according to its action, uses and the TCM theory of five flavors, that it has sweet and bitter taste. This means that, while sweet taste drugs can replenish, reconcile, promote smelting, nourish, tonify and relieve pain, bitter taste drugs can release, dry, clear the heat and purge the fire, induce venting, reversing energy (qi) and moving stool. Most of medicinal plants that store yin (organic substance) has a bitter taste with laxative action softening of hard stools and reducing infectious diseases with the cooling effect. Moringa oleifera leaves can also decrease fat in blood and promote weight loss, which is also according to its bitter taste. Moringa oleifera fresh leaves have acrid and bitter taste, while the dried M. oleifera powder has a lighter taste and less bitter taste. Moreover, the modern research indicates that in bitter medicinal plants contain mostly alkaloids and glycosides, although, having sour ingredients, mainly phenolic acid, tannin, etc.

In general, all these aspects may suggest that $M$. oleifera presents natural compounds with manly antipyretic, qireleasing, clearing heat, laxative, replenishing and bloodactivating effects.

On the other hand, the sweet taste in medicinal plants means that contains many sugars, glycosides, amino acids, proteins and vitamins. Moringa oleifera leaves contain rich nutritional value and can be used to nourish children that has severe malnutrition and lack of trace elements, so being inferred as a tonic effect plant. In addition, studies have shown that methanol extract from $M$. oleifera leaves presents obvious analgesic effect (Adedapo et al. 2015) which agree to the most analgesic natural drugs compounds that have sweet taste. Moringa oleifera leaves with reducing role of the body's inflammatory response can treat malaria, typhoid, etc. (Waterman et al. 2014; Udosen et al. 2016; Donkor et al. 2015; Dondee et al. 2016). Finally, although not present in $M$. oleifera, salty natural drugs often contain inorganic salts and proteins (Zhang and Liu 2015) which can dissipate nodules, light, permeable, and water-wetting drugs, maintaining and retaining humidity, whereas the acid drugs can receive, astringent, and generally stop sweating, constricting lungs, cough, astringent intestines, diarrhea, urine.

In summary, the above natural effects described in research are consistent with the nutritional, tonic and analgesic efficacy of sweet natural medicinal drugs. 
Energetic meridian tropism-TCM medicinal plants are energetically categorized in by its nature or temperature, taste, movement with ascend or descend effect and meridian organ tropism. Ascend and descend movements will demonstrate if the herb has an upward or floatation in preference to a downward or sedimentation effect in the body. Concerning $M$. oleifera leaves it is believed to have cold and bitter tastes (Litao and Hongmin 2001), having antihypertensive effect and promoting defecation, considering that we may speculate that $M$. oleifera belongs to sedimentation drugs with downward or descendent movement.

The meridian organ tropism is mainly inferred by the action of M. oleifera leaves having the effect of treating liver dysfunction and lowering blood pressure, which can be attributed to the liver meridian. M. oleifera leaves also stimulate lactation, which is related with liver and/or stomach meridians.

In terms of western medicine clinical uses, $M$. oleifera leaves can treat malnutrition, obesity, and lipid-lowering effects (Jain et al. 2010). Those are closely related to the spleen meridian. Therefore, it is a strong possibility that $M$. oleifera leaf actions belong to the liver, spleen and/or stomach meridians.

Through the 238 kinds of analysis of flavored drugs, Wang (2002) found that sweet flavored natural drugs mostly are related to the liver, lung and stomach meridians; the bitter taste medicines are mostly redirected to the liver and stomach meridians; the acid drugs are mostly redirected to the liver, stomach, lung and spleen meridians; salty drugs mostly belongs to liver and kidney meridians. So, since $M$. oleifera leaves exhibit sweet and bitter flavor, this reinforce clearly its action on the liver, spleen and/or stomach meridian as well as its beneficial effect on treating malnutrition and on regulating blood sugar levels in people with diabetes which is mostly qi-yin deficiency in TCM energetic syndrome differentiation. According to TCM categorization spleen and stomach meridians belong to earth element.

Moringa oleifera leaves are cold, which has anti-inflammatory effect, lowering the fever, can also reduce the body's metabolism, therefore allowing to speculated that M. oleifera leaves have a cooling effect in the body. M. oleifera leaves also have a lipid-lowering, weight-loss, and arterial plaque improvement. On the other hand, in TCM system a pharmacological action on the obesity and arterial plaque is mostly considered to exhibit a manifestation on phlegm and so, $M$. oleifera leaves may have a dehumidifying effect, eliminating dampness and phlegm. The prevention and management of hypertension are major public-health challenges (Qi Hua et al. 2019), being TCM herbs regularly advocated for lowering elevated blood pressure needing a new understanding between ancient and modern times treatment on this subject (Xiong et al. 2013). Moringa oleifera leaves can reduce blood pressure and protect liver and kidney (Leone et al. 2015a, b). In TCM system the cause of hypertension is mainly due to hyperactivity of liver yang, phlegm and turbidity (Shao et al. 1999). The heat-relieving properties of $M$. oleifera leaves, clear the liver meridian heat removing phlegm and redirect energy to the spleen and/or stomach meridians, also strengthen the spleen and eliminate the dampness.

Curiously, attending the new global and dramatic situation concerning the corona-virus, Yang (2020), vice-leader of the Chinese Expert Medical Group for fighting Covid19 in Italy, said in a recent international videoconference, that modern Chinese medical doctors putted forward a new concept to combat and block this pulmonary disease. This concept propose the use of heavy dose bitter and cold herbs in order to clear heat and detoxify purging the infection in the early stage as well as to cool blood and remove blood stasis promptly in the middle and late stages. So, according all properties described above mainly to the leaf part of $M$. oleifera, such as sweet and bitter taste, cold, venting and dehumidifying inductor with descendent effect, can also make it an eventual and excellent candidate for treating the general deep alterations in immunological system involved in this disease. Moreover, all symptoms concerning hypertension, cardiovascular disease, diabetes, obesity, lung disease/asthma, kidney disease, liver disease, hematological disorders/anemia, when associated to the Covid-19 infection, will complicate intense and seriously the organism health. So, having present all immunological and specific properties and applications already inferred to M. oleifera, it is possible to speculate an adequate and supportive therapy in the corona-virus infection when combined with western medicine.

In summary, M. oleifera due to the above TCM properties can treat hyperthyroidism caused by hyperpyrexia of liver, clearing liver fire and phlegm-dampness; hypertension caused by excessive rising of liver yang or retention of phlegmatic dampness; phlegm, obesity and diabetes caused by spleen deficiency and phlegm turbid stagnation (Inbathamizh 2013; Al-Asmari et al. 2015; Gopalakrishnan et al. 2016; Fahey 2017; Dong et al. 2019). All these pathologies that benefit with $M$. oleifera treatment allow us to infer and confirm its TCM specific properties (Tables 6, 7).

Important to notice that Ayurvedic tradition have a more detailed and rich description about the pharmacological actions and clinical uses, as well as psychological effects of the different parts of $M$. oleifera, suggesting a much longer tradition using this plant in their daily life in Indian continent population. Moringa oleifera was only introduced to China from India in the 1960s and had been cultivated on a large scale for ornament in southern provinces of China. So, it is quite understandable that India possess much more traditional and scientific medical knowledge about $M$. oleifera than in Chinese culture. Although only recently introduced 


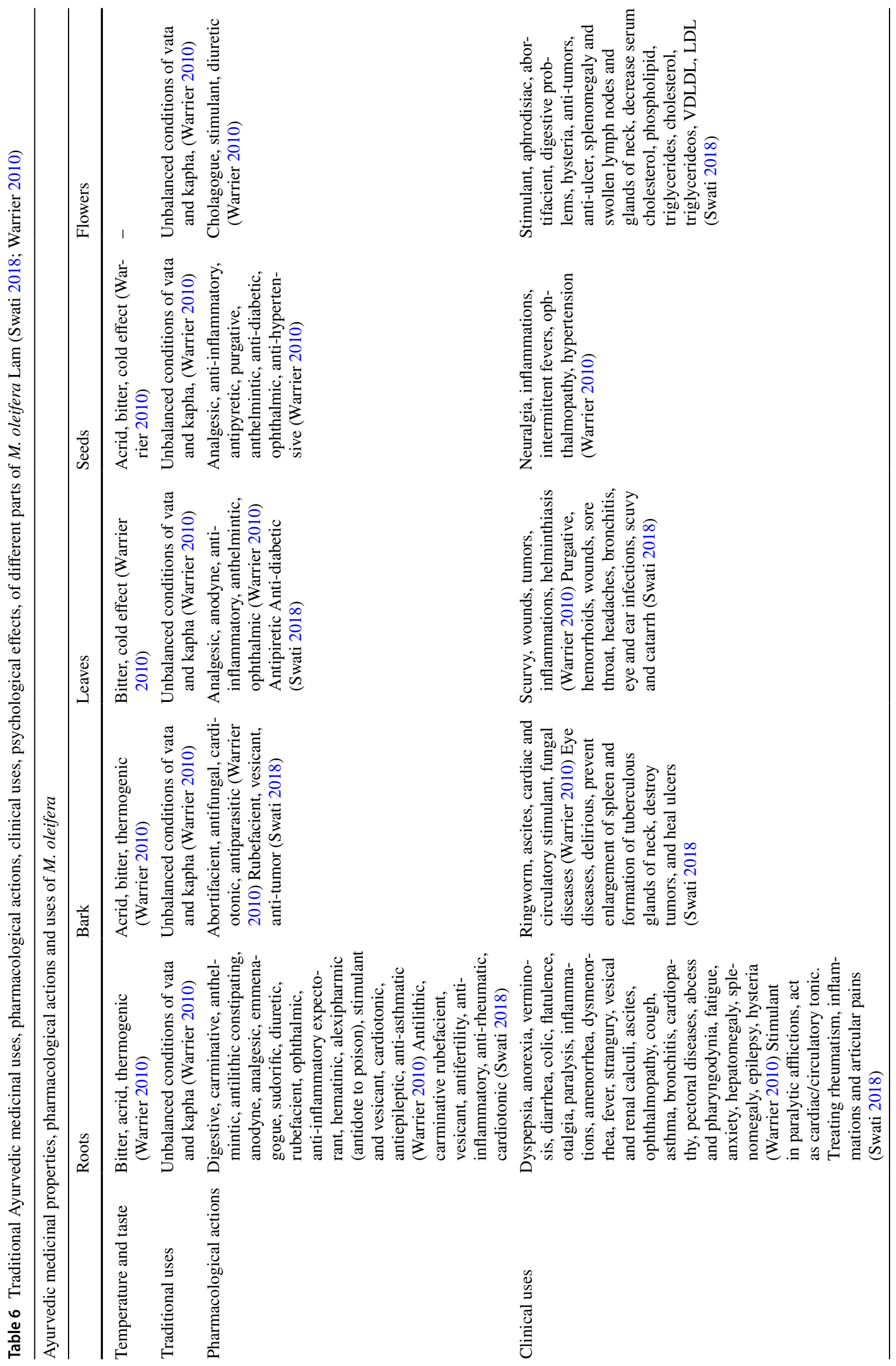




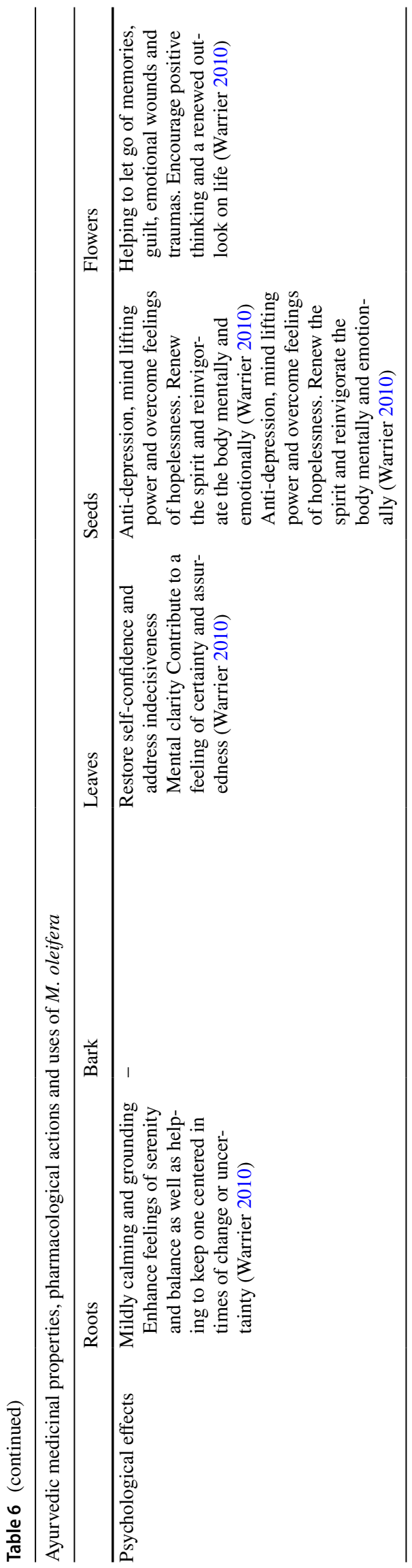

to China, due to its valuable medicinal properties, TCM experts recognize its value and categorize it according to their own principles, so that can be clinically used as a TCM natural drug.

In this literature research about $M$. oleifera in both ancient systems of medicine (India and China) we could observe some common views about this tree.

In both traditional culture the roots and bark of $M$. oleifera are considered acrid and warm in temperature, being appropriated to treat constitutional deficiency type. But, based in TCM concepts, its leaves are considered of bitter, sweet and cold nature which can be used in excess energetic syndromes, such us hyperthyroidism, hypertension, inflammations, fever, diabetes, constipation, etc. On another side, supported on trace elements and organic compounds (mentioned above), its leaves contain rich nutritional value since that, according TCM principles, has a tonifying effect of the spleen and stomach increasing the absorption and nutrients transport, which is indicated for the lack of energy and internal dampness being beneficial to tiredness, malnutrition, digestive problems, low appetite and anemic states.

Based on TCM principles, one can state that the most predominant action of $M$. oleifera leaves is to treat excess syndrome diseases mainly supported by its bitter taste and cooling temperature effect, clearing the excess heat and phlegm from the liver meridian, but at same time can have a strengthening effect in spleen and stomach meridians due to the sweet taste which can also have a nourishing effect in the body.

In Ayurvedic Medicine tradition, M. oleifera roots are clinically used to treat epilepsy, hysteria, cardiac diseases, colic and flatulence, as well as anxiety. All these diseases correspond to an excess of Vatta, which force can cause nerve irritation, high blood pressure, flatulence and confusion.

Moringa oleifera leaves are clinically used to treat catarrh, bronchitis, sore throat, headaches, constipations, which corresponds to an excess of Kapha which causes the tendency to produce mucous and obstruction in the sinus and nasal passages, lungs and colon.

Moringa oleifera seeds are clinically used to treat hypertension, neuralgia indicating an excess of Vata, and to treat constipation which belongs to an excess of kapha.

Both traditional Asian medicines reported anti-inflammatory, analgesic, antiparasitic, anti-hypertensive, hypolipidemic, hypoglycemic, diuretic effects, and help in several gastro-intestinal, gynecological and dermatology problems. Anti-aging and strength immunity are also documented, mentioning both its potential in removing toxins from the body.

In terms of influencing the mind, M. oleifera, anti-depressive and anxiolytic effects was tested and confirmed by scientific research (Kaur et al. 2015). It was further considered 


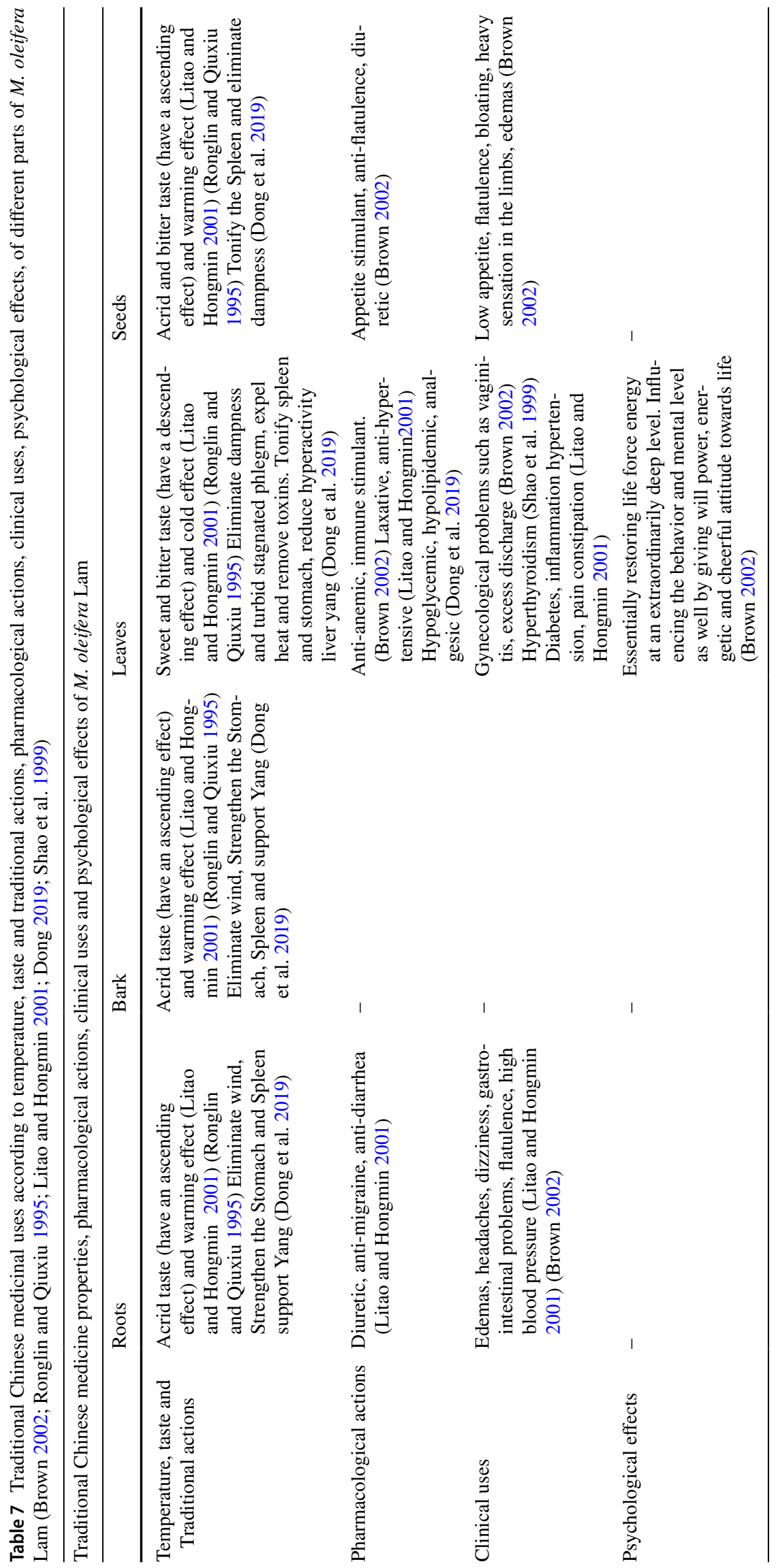


an adaptogenic and anti-stress herb (Drue 2018). Modern research about Moringa is aligned with both Ayurvedica and Traditional Chinese Medicine tradition, proving that the leaves of Moringa are super nourishing of the body, as well reporting tremendous benefits in a wide range of diseases, having also the capacity in renewing the body tissues and reinvigorate the mind and promote a positive emotional state.

Therefore, we could say that $M$. oleifera leaves are a natural supplement that works well at all levels of health and wellbeing. Whether to nourish the body, treating and preventing many diseases, or as well used as cosmetics for skin, and contributing for an energetic and positive state of mind.

\section{Summary}

Moringa oleifera can be part on solving a variety of health problems, diseases, vitamins deficiency, malnutrition and, at the same time, being a useful natural resource to the population and industry. Recently, more studies have been done to identify $M$. oleifera proteins and their functions (Wang et al. 2016). However, for the most of the $M$. oleifera properties studied, the active molecules in the extracted compounds are still to be determined, as well as the mechanisms essential to explain the medicinal properties observed and the safety of the crude extracts. Therefore, $M$. oleifera deserves extensive investigation to better explain the mechanisms of action. The better understanding of $M$. oleifera composition and properties, as well as the isolation of active compounds, may attract attention to its usefulness in nutrition (as a health promoting supplement), for new drug development and other applications such as water purification (allowing a sustainable and low-cost water treatment), production of biodiesel and cosmetics. Therefore, increasing $M$. oleifera plantation in countries with scarce resources, both for popular use and for exportation of $M$. oleifera tree parts and byproducts, could boost the local trade and employment, since with correct information about the properties and cultivation rules (Bhargave 2015; Ojiako 2011). Citing Mahmood et al. (2010), $M$. oleifera is a "high quality gift of nature at very low price". According to traditional Asian medicines different parts of M. oleifera has a very large and correct therapeutic applications which depend on diagnose concerning somatic, emotional and spiritual needs. In general, $M$. oleifera penetrates deeply into the body's tissues and particularly into the bone marrow itself cleaning all impurities, toxins, parasites and metabolic wastes. This induces the renovation of cells influencing to the mind and personality with a high positive and confidence feelings. It is a potent rebuilder of marrow in the body, essentially restoring life force energy at an extraordinarily deep level.
Traditionally in TCM the leaves of $M$. oleifera are considered to be bitter and sweet with a descending and cooling effect, which can clear the excess heat and phlegm from the liver meridian, but at same time can have a strengthening effect in spleen and stomach meridians due to the sweet taste and rich nutritional value (Dong et al. 2019). In Ayurvedic Medicine, $M$. oleifera leaves among other diseases are clinically used to treat catarrh, bronchitis, sore throat, headaches, constipations, which corresponds to an excess of Kapha constitution type that normally causes the tendency to produce mucous and obstruction in the sinus and nasal passages, the lungs and colon (Miller 1998; Ninivaggi 2010). This study provides an integrative approach on conventional and traditional Asian medicine properties, nutritional and pharmaceutical applications of $M$. oleifera. So, comparatively, it seems possible to correlate concepts concerning Warm versus Vata effects and Cold versus Kapha effects in TCM and Ayurveda medicines, respectively, which can even add great value in confirming and completing any lack of therapeutic information.

Taking into consideration the empirical knowledge of traditional Asian medicine and their own paradigm-based medicine, future research studies are required to validate or understand their mechanism of energetic categorization and their actions, opening new ideas and horizons, as that on the Covid-19 disease effect, for a more correct, scientific and clinical application of $M$. oleifera.

Acknowledgements We would like to thank Dr. Rodrigo Silva, a clinical consultant of Naturinga Company in Portugal, for its friendly help in stimulating our interest in this natural and medicinal plant. We thanks also Bruno Ramos of ICBAS-UP who kindly support the informatics assistance in the composition of table and manuscript format.

Funding This research did not receive any specific Grant from funding agencies in the public, commercial, or not-for-profit sectors.

\section{Compliance with ethical standards}

Ethical statement This article does not contain any studies with human participants or animals performed by any of the authors.

Conflict of interest Diana Meireles has no conflict of interest. João Gomes has no conflict of interest. Lara Lopes has no conflict of interest. Mariana Hinzmann has no conflict of interest. Jorge Machado has no conflict of interest.

\section{References}

Abdull Razis AF, Ibrahim MD, Kntayya SB (2014) Health benefits of Moringa oleifera. Asian Pac J Cancer Prev APJCP 15:8571-8576

Adedapo A, Mogbojuri O, Emikpe B (2009) Safety evaluations of the aqueous extract of the leaves of Moringa oleifera in rats. J Med Plants Res 3:586-591 
Adedapo A, Falayi O, Oyagbemi A (2015) Evaluation of the analgesic, anti-inflammatory, anti-oxidant, phytochemical and toxicological properties of the methanolic leaf extract of commercially processed Moringa oleifera in some laboratory animals [J]. J Basic Clin Physiol Pharmacol 26(5):491-499

Al-Asmari AK, Albalawi SM, Athar MT, Khan AQ, Al-Shahrani $\mathrm{H}$, Islam M (2015) Moringa oleifera as an anti-cancer agent against breast and colorectal cancer cell lines. PLoS ONE 10:e0135814. https://doi.org/10.1371/journal.pone.0135814

Ali A, Akhtar N, Khan MS, Khan MT, Ullah A, Shah MI (2013a) Effect of Moringa oleifera on undesirable skin sebum secretions of sebaceous glands observed during winter season in humans. Biomed Res 24:8571-8576

Ali A, Akhtar N, Khan MS, Rasool F, Iqbal FM, Khan MT, Din MU, Elahi E (2013b) Moisturizing effect of cream containing Moringa oleifera (Sohajana) leaf extract by biophysical techniques: in vivo evaluation. J Med Plants Res 7:386-391

Ali A, Akhtar N, Mumtaz AM, Khan MS, Iqbal FM, Zaidi S (2013c) In vivo skin irritation potential of a cream containing Moringa oleifera leaf extract. African J Pharm Pharmacol 7:289-293

Ali A, Akhtar N, Chowdhary F (2014) Enhancement of human skin facial revitalization by moringa leaf extract cream. Postepy Dermatol Alergol 31:71-76. https://doi.org/10.5114/ pdia.2014.40945

Ali A, Yusof A, Chin L, Ibrahim MN, Muneer S (2019) Development and standardization of Moringa oleifera leaves as a natural dietary supplement[J]. J Diet Suppl 16(1):66-85. https://doi. org/10.1080/19390211.2018.1429517

Al-Malki AL, El Rabey HA (2015) The antidiabetic effect of low doses of Moringa oleifera Lam. seeds on streptozotocin induced diabetes and diabetic nephropathy in male rats. BioMed Res Int ID381040:1-13. https://doi. org/10.1155/2015/381040

Annongu A, Karim O, Toye A, Sola-Ojo F, Kayode R, Badmos A, Alli O, Adeyemi K (2014) Geo-Assessment of chemical composition and nutritional Evaluation of Moringa oleifera seeds in nutrition of Broilers. J Agric Sci 6:119

Anthanont P, Lumlerdkij N, Akarasereenont P, Vannasaeng S, Sriwijitkamol A (2016) Moringa oleifera leaf increases insulin secretion after single dose administration: a preliminary study in healthy subjects. J Med Assoc Thailand Chotmaihet Thangphaet 99:308-313

Anwar F, Ashraf M, Bhanger MI (2005) Interprovenance variation in the composition of Moringa oleifera oil seeds from Pakistan. J Am Oil Chem Soc 82:45-51

Anwar F, Latif S, Ashraf M, Gilani AH (2007) Moringa oleifera: a food plant with multiple medicinal uses. Phytother Res: PTR 21:17-25. https://doi.org/10.1002/ptr.2023

Asare GA, Gyan B, Bugyei K, Adjei S, Mahama R, Addo P, OtuNyarko L, Wiredu EK, Nyarko A (2012) Toxicity potentials of the nutraceutical Moringa oleifera at supra-supplementation levels. J Ethnopharmacol 139(1):265-272

Asiedu-Gyekye IJ, Frimpong-Manso S, Awortwe C, Antwi DA, Nyarko AK (2014) Micro- and macroelemental composition and safety evaluation of the nutraceutical Moringa oleifera leaves. J Toxicol ID 786979:1-13. https://doi.org/10.1155/2014/786979

Aslam M, Anwar F, Nadeem R, Rashid U, Kazi TG, Nadeem M (2005) Mineral composition of Moringa oleifera leaves and pods from different regions of Punjab, Pakistan. Asian J Plant Sci 4:417-421

Baldisserotto A, Buso P, Radice M, Dissette V, Lampronti I, Gambari R, Manfredini S, Vertuani S (2018) Moringa oleifera leaf extracts as multifunctional ingredients for "Natural and Organic" sunscreens and photoprotective preparations. Mol (Basel, Switzerland) 23(3):664. https://doi.org/10.3390/molecules23030664
Barichella M, Pezzoli G, Faierman SA, Raspini B, Rimoldi M, Cassani E, Bertoli S, Battezzati A, Leone A, Iorio L (2019) Nutritional characterisation of Zambian Moringa oleifera: acceptability and safety of short-term daily supplementation in a group of malnourished girls. Int J Food Sci Nutr 70:107-115. https://doi. org/10.1080/09637486.2018.1475550

Bharali R, Tabassum J, Azad MR (2003) Chemomodulatory effect of Moringa oleifera, Lam, on hepatic carcinogen metabolising enzymes, antioxidant parameters and skin papillomagenesis in mice. Asian Pac J Cancer Prev APJCP 4:131-139

Bhargave A, Pandey I, Nama KS, Pandey M (2015) Moringa oleifera Lam. Sanjana (horseradish tree) - a miracle food plant with multipurpose uses in Rajasthan-India-an overview. Int J Pure Appl Biosci 3:237-248

Bhat SKJA (2014) (2014) Antianxiety effect of ethanolic extract of leaves of Moringa oleifera in Swiss albino mice. Arch Med Health Sci 2:5-7

Botsaris AS (2002) Introdução à Fitoterapia Chinesa In: Fitoterapia chinesa e plantas brasileiras. $2^{a}$ Edição, Cone Editora. São Paulo, Brasil, pp 19-27

Brown D (2002) The royal horticultural society- encyclopedia of herbs and their uses. Dorling Kindersley Limited, London

Cáceres A, Saravia A, Rizzo S, Zabala L, De Leon E, Nave F (1992) Pharmacologie properties of Moringa oleifera. 2: screening for antispasmodic, antiinflammatory and diuretic activity. J Ethnopharmacol 36:233-237

Choudhary MK, Bodakhe SH, Gupta SK (2013) Assessment of the antiulcer potential of Moringa oleifera root-bark extract in rats. J Acupunct Meridian Stud 6:214-220. https://doi.org/10.1016/j. jams.2013.07.003

Das N, Sikder K, Ghosh S, Fromenty B, Dey S (2012) Moringa oleifera Lam. leaf extract prevents early liver injury and restores antioxidant status in mice fed with high-fat diet. Indian J Exp Biol 50:404-412

Dasgupta N, De, (2007) Antioxidant activity of some leafy vegetables of India: A comparative study. Food Chem 101(2):471-474

Debajyoti D, Dipsundar S, Dinesh B, Chandreyee R, Sanatan R, Jayram H (2017) Moringa olifera (shigru): a miracle tree for its nutritional, ethnomedicinal and therapeutic importance. Int J Dev Res-IJDR 07(11):16823-16827

Delaveau P, Boiteau P (1980) oil of pharmacological, cosmetic and dietetic interest: VI-Oils of Moringa oleifera Lam and Moringa drouhardii Jumelle. Plantes Méd Phytothér 14(10):29-33

Divya KG, Rubeena M, Andalil R, Erni B, Sundaramoorthy B, Thatipelli S, Koppala Narayana Sunil Kumar KNS, Shakila R (2019) Identity profile of Moringa oleifera Lam. Flower Int J Bot Stud 4(4):90-99

Dixit S, Tripathi A, Kumar P (2016) Medicinal properties of Moringa oleifera: a review. Int J Edu Sci Res 3(2):173-185

Dondee K, Bootprom P, Saiphet B, Borkaew P, Klubsri C, Somsak V (2016) Antimalarial activities of Moringa oleifera leaf extract against plasmodium berghei anka infection in icr mice. Int $\mathrm{J}$ Innov Res Med Sci (IJIRMS) 1(5):194-201

Dong X, Guo X, Hu Y et al (2019) Summary of studies on traditional Chinese medicine properties of overseas plant medicine Moringa leaves. Glob Tradit Chinese Med 12(1):149-153 (10.3969/j. issn.1674-1749.2019.01.050)

Donkor AM, Oduro-Mensah D, Ani E, Ankamah E, Nsiah S, Mensah DE, Dickson EK, Kusi KA (2015) In vitro anti-plasmodial activity of aqueous and ethanolic extracts of Moringa oleifera and phyllanthus amarus. Int J Biol Chem 9(4):198-206

Drue GEHS, Minor RC (2018) Moringa oleifera tea alters neutrophil but not lymphocyte levels in blood of acutely stressed mice. Madridge J Immunol 2:43-48 
Dutta AK (2017) Moringa oleifera: a Review on its importance and medicinal applications in recent age. World J Pharm Sci 6:1829-1843

Ellis WO, Oduro I, Owusu D (2011) Development of crackers from cassava and sweetpotato flours using Moringa oleifera and Ipomoea batatas leaves as fortificant. Am J Food Nutr 1:114-122

Ezeamuzie IC, Ambakederemo AW, Shode FO, Ekwebelem SC (1996) Anti-inflammatory effects of Moringa oleifera root extract. Int J Pharmacogn 34:207-212

Fahey JW, Zalcmann AT, Talalay P (2001) The chemical diversity and distribution of glucosinolates and isothiocyanates among plants. Phytochemistry 56:5-51. https://doi.org/10.1016/S0031 $-9422(00) 00316-2$

Fahey J (2005) Moringa oleifera: a review of the medical evidence for its nutritional, therapeutic, and prophylactic properties. Part 1. Trees Life J 1(5):1-15. https://doi.org/10.1201/9781420039 078.ch12

Fahey J (2017) Moringa oleifera: a review of the medical potential. Acta Hort 1158:209-224

Faizi S, Siddiqui, BS, Saleem R, Aftab K, Shaheen F, Gilani AH (1998) Bioactive compounds from the leaves and pods of Moringa oleifera. New trends in natural products chemistry 175-183

Chen FW (1998) A comprehensive chinese-latin-english dictionary of the chinese herbal medicines. World Books Publishing Corp, Xi' an, China, p 227

Fuglie LJ (1999) The miracle tree: moringa oleifera, natural nutrition for the tropics. Church World Service, Dakkar, Senegal, pp 68

Ghiridhari VVA, Malhati D, Geetha K (2011) Anti-diabetic properties of drumstick (Moringa oleifera) leaf tablets. Int J Health Nutr 2:1-5

Gholap S, Kar A (2004) A Hypoglycemic effects of some plant extracts are possibly mediated through inhibition in corticosteroid concentration. Pharmazie 59:876-878

Gopalakrishnan L, Doriya K, Kumar DS (2016) Moringa oleifera: a review on nutritive importance and its medicinal application. Food Sci Human Wellness 5:49-56

Gothai S, Arulselvan P, Tan WS, Fakurazi S (2016) Wound healing properties of ethyl acetate fraction of Moringa oleifera in normal human dermal fibroblasts. J Intercult Ethnopharmacol 5:1-6. https://doi.org/10.5455/jice.20160201055629

Guiguer L, Barbalho SM, Bueno P, Mendes CG, Oshiiwa M, Menezes ML, Marinelli PS, Santos PC, Santos MC, Leticia Maria Salzedas LM, Nicolau CC, Otoboni AM (2016) Consumption of Moringa oleifera flour and its effects on the biochemical profile and intestinal motility in an animal model. Int J Phytomed 8(3):427-434. https://doi.org/10.5138/09750185.1845

Gupta SC, Kim JH, Prasad S, Aggarwal BB (2010) Regulation of survival, proliferation, invasion, angiogenesis, and metastasis of tumor cells through modulation of inflammatory pathways by nutraceuticals. Cancer Metastasis Rev 29(3):405-434. https:// doi.org/10.1007/s10555-010-9235-2

Hameed-Un-Nisa L, Shehnaz D, Faizi S (1998) Measurement of sympatholytic activity of Moringa oleifera. New Trends in Natural Products Chemistry [6th International Symposium on Natural Products Chemistry]. Harwood Amsterdam, pp 269-277

Hamza AA (2007) Curcuma longa, Glycyrrhiza glabra and Moringa oleifera ameliorate diclofenac-induced hepatoxicity in rats. Am J Pharmacol Toxicol 2:80-88

Hamza AA (2010) Ameliorative effects of Moringa oleifera Lam seed extract on liver fibrosis in rats. Food Chem Toxicol 48(1):345355. https://doi.org/10.1016/j.fct.2009.10.022

Hua Qi, Fan Li, Li J, Joint Committee for Guideline Revision (2019) Chinese guideline for the management of hypertension in the elderly. J Geriatr Cardiol 16(2):67-99. https://doi.org/10.11909 /j.issn.1671-5411.2019.02.001
Inbathamizh L, Padmini E (2013) Evaluation of growth inhibitory potential of Moringa oleifera flowers on PC3 cell lines. Asian J Pharm Clin Res 6:60-64

Jadoon S, Karim S, Bin Asad MHH, Akram MR, Khan AK, Malik A, Chen C, Murtaza G (2015) Anti-aging potential of phytoextract loaded-pharmaceutical creams for human skin cell longetivity. Oxid Med Cell Longev 2015(ID709628):1-17. https://doi. org/10.1155/2015/709628

Jain PG, Patil SD, Haswani NG, Girase MV, Surana SJ (2010) Hypolipidemic activity of Moringa oleifera Lam., Moringaceae, on high fat diet induced hyperlipidemia in albino rats. Rev Bras Farmacogn 20:969-973

Jha N, Mohanka R, Azad R (2009) Antifungal investigation of the constituents of Moringa oleifera Lam root bark extract. Asian J Chem 21(9):7437-7439

Ji Chang W (2002) Analysis on the theory of Chinese herbal flavor. J Anhui Univ Tradit Chinese Med 21(1):4-6

Jung KI (2016) Quality Characteristics of muffins added with Moringa (Moringa oleifera Lam.) leaf powder. J Korean Soc Food Sci Nutr 45:872-879

Kansal SK, Kumari A (2014) Potential of M. oleifera for the treatment of water and wastewater. Chem Rev 114:4993-5010. https://doi. org/10.1021/cr400093w

Karadi RV, Gadge NB, Alagawadi KR, Savadi RV (2006) Effect of Moringa oleifera Lam root-wood on ethylene glycol induced urolithiasis in rats. J Ethnopharmacol 105:306-311. https://doi. org/10.1016/j.jep.2005.11.004

Kasote DM, Jagtap SD, Thapa D, Khyade MS, Russell WR (2017) Herbal remedies for urinary stones used in India and China: a review. J Ethnopharmacol 203:55-68. https://doi.org/10.1016/j. jep.2017.03.038

Kaur G, Invally M, Sanzagiri R, Buttar HS (2015) Evaluation of the antidepressant activity of Moringa oleifera alone and in combination with fluoxetine. J Ayurveda Integr Med 6:273-279. https:// doi.org/10.4103/0975-9476.172384

Kelly G (2000) Peripheral metabolism of thyroid hormones: a review. Altern Med Rev 5(4):306-333

Kirisattayakul W, Wattanathorn J, Tong-Un T, Muchimapura S, Wannanon P, Jittiwat J (2013) Cerebroprotective effect of Moringa oleifera against focal ischemic stroke induced by middle cerebral artery occlusion. Oxid Med Cell Longev 2013(ID951415):1-10. https://doi.org/10.1155/2013/951415

Kraiphet S, Butryee C, Rungsipipat A, Budda S, Rattanapinyopitak K, Tuntipopipat S (2018) Apoptosis induced by Moringa oleifera Lam. pod in mouse colon carcinoma model. Comp Clin Pathol 27:21-30

Krishnamurthy PT, Vardarajalu A, Wadhwani A, Patel V (2015) Identification and characterization of a potent anticancer fraction from the leaf extracts of Moringa oleifera Lam. Indian J Exp Biol 53:98-103

Kurma SR, Mishra SH (1998) Hepatoprotective principles from the stem bark of Moringa pterygosperma. Pharm Biol 36:295-300

Lea M (2010) Bioremediation of turbid surface water using seed extract from Moringa oleifera Lam (drumstick) tree. Curr Protoc Microbiol. https://doi.org/10.1002/9780471729259.mc01g02s16

Lea M (2014) Bioremediation of turbid surface water using seed extract from the Moringa oleifera Lam (Drumstick) tree. Curr Protoc Microbiol 33:1G.2.1-8. https://doi.org/10.1002/9780471729259. mc01g02s33

Leone A, Fiorillo G, Criscuoli F, Ravasenghi S, Santagostini L, Fico G, Spadafranca A, Battezzati A, Schiraldi A, Pozzi F, di Lello S, Filippini S, Bertoli S (2015a) Nutritional characterization and phenolic profiling of Moringa oleifera leaves grown in chad, sahrawi refugee camps, and haiti. Int J Mol Sci 16(8):18923-18937. https://doi.org/10.3390/ijms160818923 
Leone A, Spada A, Battezzati A, Schiraldi A, Aristil J, Bertoli S (2015b) Cultivation, genetic, ethnopharmacology, phytochemistry and pharmacology of Moringa oleifera leaves: an overview [J]. Int J Mol Sci 16(6):12791-12835

Litao Y, Hongmin $\mathrm{Hu}$ (2001) The material basis of drug theory. Forum Tradit Chin Med 16(2):47-47

Liu G, Qiuping J, Wang T (2003) The essentials of traditional Chinese herbal medicine. Foreigner Language Press, Beijing (ISBN)9787119024134

Liwu Y, Dongmei Z, Yuedong Li (2002) The medicinal properties of cold medicine and its compatibility analysis. Xinjiang J Tradit Chin Med 20(4):39-41

Mahajan SG, Mali RG, Mehta AA (2007) Protective effect of ethanolic extract of seeds of Moringa oleifera lam against inflammation associated with development of arthritis in rats. J Immunotoxicol 4(1):39-47

Mahmood KT, Mugal T, Haq IU (2010) Moringa oleifera : a natural gift-a review. J Pharm Sci Res 1:775-781

Mainenti D (2018) Moringa oleifera: a prolific herbal research front. Inf Sci Bibliometr DIS803:1-4

Maizuwo AI, Hassan AS, Momoh H, Muhammad JA (2017) Phytochemical constituents, biological activities, therapeutic potentials and nutritional values of Moringa oleifera (Zogale): a review. Jour Drug Des Med 3(4):60-66

Maurya SK, Singh AK (2014) Clinical efficacy of Moringa oleifera Lam stems bark in urinary tract infections. Int Sch Res Notices 2014(ID906843):1-7. https://doi.org/10.1155/2014/906843

Mbikay M (2012) Therapeutic Potential of Moringa oleifera leaves in chronic hyperglycemia and dyslipidemia: a review. Front Pharmacol 3:24. https://doi.org/10.3389/fphar.2012.00024

McKnight M, Allen J, Waterman JT, Hurley S, Idassi J, Minor RC et al (2014) Moringa tea blocks acute lung inflammation induced by swine confinement dust through a mechanism involving TNF-a expression, c-jun n-terminal kinase activation and neutrophil regulation. Am Jour Immunol 10(2):73-87

Miller L, Miller B (1998) Aromatherapy and the correction of dosha imbalance In: Ayurveda and Aromatherapy - the earth essential guide to ancient wisdom and modern healing. Lotus Press, Motilal Banarsidass Publishers PVT.Ltd (Delhi -India), pp 93-108

Moyo B, Masika PJ, Hugo A, Muchenje V (2011) Nutritional characterization of Moringa (Moringa oleifera Lam.) leaves. Afr J Biotech 10:12925-12933

Muhammad AA, Pauzi NA, Arulselvan P, Abas F, Fakurazi S (2013) In vitro wound healing potential and identification of bioactive compounds from Moringa oleifera Lam. BioMed Res Int 2013(ID974580):1-10. https://doi.org/10.1155/2013/974580

Nadeem M, Imran M (2016) Promising features of Moringa oleifera oil: recent updates and perspectives. Lipids Health Dis 15:212. https://doi.org/10.1186/s12944-016-0379-0

Nambiar VS, Guin P, Parnami S, Daniel M (2010) Impact of antioxidants from drumstick leaves on the lipid profile of hyperlipidemics. J Herb Med Toxicol 4:165-172

Nath D, Sethi N, Srivastad S (1997) Survey on indigenous medicinal plants used for abortion in some districts of Uttar Pradesh. Fitoterapia $68(3): 223-225$

Ninivaggi F (2010) Ayurveda: a comprehensive guide to traditional indian medicine for the west. Rowman and Littlefield Publishers, Lanham

Oduro I, Ellis WO, Owusu D (2008) Nutritional potential of two leafy vegetables: Moringa oleifera and Ipomoea batatas leaves. Sci Res Essay 3:57-60

Ojiako FO, Adikuru NC, Emenyonu CA (2011) Critical issues in investment, production and marketing of Moringa oleifera as an industrial agricultural raw material in Nigeria. J Agric Res Dev 10:39-56
Olson MEFJ (2011) Moringa oleifera: un árbol multiusos par las zonas tropicales secas. Rev Mexicana Biodivers 82:1071-1082

Olson ME, Sankaran RP, Fahey JW, Grusak MA, Odee D, Nouman W (2016) Leaf protein and mineral concentrations across the "Miracle Tree" genus Moringa. PLoS ONE 11(7):1-17. https:// doi.org/10.1371/journal.pone.0159782

Praengam K, Muangnoi C, Dawilai S, Awatchanawong M, Tuntipopipat S (2014) Digested Moringa oleifera boiled pod exhibits antiinflammatory activity in Caco-2 cells. J Herbs Spices Med Plants 21(2):148-160. https://doi.org/10.1080/10496475.2014.932880

Rani A, Husain K, Kumolosasi E (2018) Moringa genus: a review of phytochemistry and pharmacology. Front Pharmacol 9(108):126. https://doi.org/10.3389/fphar.2018.00108

Rashid U, Anwar F, Moser BR, Knothe G (2008) Moringa oleifera oil: a possible source of biodiesel. Bioresour Technol 99:8175-8179. https://doi.org/10.1016/j.biortech.2008.03.066

Rebufa C, Pany I, Bombarda I (2018) NIR spectroscopy for the quality control of Moringa oleifera (Lam.) leaf powders: prediction of minerals, protein and moisture contents. Food Chem 261:311321. https://doi.org/10.1016/j.foodchem.2018.04.066

Rockwood JL, Anderson BG, Casamatta DA (2013) Potential uses of Moringa oleifera and an examination of antibiotic efficacy conferred by $M$. oleifera seed and leaf extracts using crude extraction techniques available to underserved indigenous populations. Int J Photother Res 3:61-71

Ronglin Y, Qiuxiu Y (1995) Comparison and analysis of trace elements in traditional Chinese medicine for cold and heat. East Trace Elem Sci 2(8):17-21

Ross J (2003) Combining western herbs and Chinese Medicine. Principles, practice and materia medica. Greenfields Press, Seatle

Ruckmani K, Kavimani S, An R, Jaykar B (1998) Effect of Moringa oleifera Lam on paracetamol-induced hepatotoxicity. Indian $\mathrm{J}$ Pharm Sci 2(4):33-35 (60)

Saini RK, Sivanesan I, Keum YS (2016) Phytochemicals of Moringa oleifera: a review of their nutritional, therapeutic and industrial significance. 3Biotech 6(203):1-14. https://doi.org/10.1007/ s13205-016-0526-3

Sa'roni SR, Sadjiman T, Sja'bani M, dan Zulaela Z (2004) Effectiveness of the sauropus androgynus (1.) Merr leaf extract in increasing mother's Breast milk production. Media Litbang Kesehat XIV 3:20-24

Senecha C, Shama PK, D'Souza UP, Shastry CS (2012) Anticholesteremic and antilipidemic activity of stem bark extracts of Moringa oleifera in diet induced hyperlipidemia model in rats. Int J Pharm Chem Sci 1(3):916-923

Shao Guangxian C, Kejian Z, Yuming H (1999) Clinical prevalence of common symptoms of hypertension. Observation of diseases [J]. J Tradit Chinese Med 40(8):492-493

Sharma P, Kumari P, Srivastava MM, Srivastava S (2006) Removal of cadmium from aqueous system by shelled Moringa oleifera Lam seed powder. Bioresour Technol 97:299-305. https://doi. org/10.1016/j.biortech.2005.02.034

Shukla S, Mathur R, Prakash AO (1988) Antifertility profile of the aqueous extract of Moringa oleifera roots. J Ethnopharmacol 22:51-62

Siddhuraju P, Becker K (2003) Antioxidant properties of various solvent extracts of total phenolic constituents from three different agroclimatic origins of drumstick tree (Moringa oleifera Lam) leaves. J Agric Food Chem 51(8):2144-2155. https://doi. org/10.1021/jf020444+

Sileshi T, Makonnen E, Debella A, Tesfaye B (2014) Antihyperglycemic and subchronic toxicity study of Moringa stenopetala leaves in mice. J Coast Life Med 2(3):214-221

Stohs SJ, Hartman MJ (2015) Review of the safety and efficacy of Moringa oleifera. Phytother Res: PTR 29:796-804. https://doi. org/10.1002/ptr.5325 
Sutalangka C, Wattanathorn J, Muchimapura S, Thukham-mee W (2013) Moringa oleifera mitigates memory impairment and neurodegeneration in animal model of age-related dementia. Oxid Med Cell Longev 2013(ID695936):1-9. https://doi. org/10.1155/2013/695936

Swati VA, Virik AK, Kumari C, Ali A, Gark P, Thakur P, Attri C, Kulshrestha S (2018) Moringa oleifera - a never die tree: an overview. Asian J Pharm Clin Res 11(12):57-65

Tahiliani P, Kar A (2000) Role of Moringa oleifera leaf extract in the regulation of thyroid hormone status in adult male and female rats. Pharmacol Res 41:319-323. https://doi.org/10.1006/ phrs.1999.0587

Titi MK, Nurjanah N (2014) Improvement of noodles recipe for increasing breastmilk: design of the moringa noodles. Am J Food Sci Technol 2(3):88-92. https://doi.org/10.12691/ajfst $-2-3-2$

Titi MK, Harijono ET, Endang SW (2013) Effect lactagogue moringa leaves (Moringa oleifera Lam) powder in rats white female wistar. J Basic Appl Sci Res 3(4):430-434

Torondel B, Opare D, Brandberg B, Cobb E, Cairncross S (2014) Efficacy of Moringa oleifera leaf powder as a hand-washing product: a crossover controlled study among healthy volunteers. BMC Complement Altern Med 14(57):1-7. https://doi. org/10.1186/1472-6882-14-57

Udosen IE, Okwori AEJ, Ijebor JA, Jonson PO, Adikwu TI (2016) Effects of Moringa oleifera leaf tea on salmonella typhi and Escherichia Coli. IOSR J Dent Med Sci (IOSR-JDMS) 15(3):62-66

Valdez-Solana MA, Mejía-García VY, Téllez-Valencia A, GarcíaArenas G, Salas-Pacheco JS, Alba-Romero JJ, Sierra-Campos E (2015) Nutritional content and elemental and phytochemical analyses of Moringa oleifera grown in Mexico. J Chem. https ://doi.org/10.1155/2015/860381

Vauzour D, Vafeiadou K, Rodriguez-Mateos A, Rendeiro C, Spencer JP (2008) The neuroprotective potential of flavonoids: a multiplicity of effects. Genes Nutr 3(4):115-126. https://doi. org/10.1007/s12263-008-0091-4

Verma AR, Vijayakumar M, Mathela CS, Rao CV (2009) In vitro and in vivo antioxidant properties of different fractions of Moringa oleifera leaves. Food Chem Toxicol 47(9):2196-2201. https:// doi.org/10.1016/j.fct.2009.06.005

Viera GH, Mourao JA, Angelo AM, Costa RA, Vieira RH (2010) Antibacterial effect (in vitro) of Moringa oleifera and Annona muricata against Gram positive and Gram negative bacteria. Rev Inst Med Trop Sao Paulo 52:129-132

Wan KCP (2001) Morphological characters and geographical distribution are the same as those for the family. Flora China 8:106
Wang L, Zou Q, Wang J, Zhang J, Liu Z, Chen X (2016) Proteomic profiles reveal the function of different vegetative tissues of Moringa oleifera. Protein J 35:440-447. https://doi. org/10.1007/s10930-016-9690-x

Warrier PK, Nambiar VPK, Ramankutty C (2010) Indian Medicinal Plants, A Compendium of 500 species, vol 4. Univerties Pres. Kottakal, India, pp 303-306

Waterman C, Cheng DM, Rojas Silva P, Poulev A, Dreifus J, Lila MA, Raskin I (2014) Stable water extractable isothiocyanates from Moringa oleifera, leaves attenuate inflammation in vitro. Phytochemistry 103:114-122

William F, Lakshminarayanan S, Chegu H (1993) Effect of some Indian vegetables on the glucose and insulin response in diabetic subjects. Int J Food Sci Nutr 44:191-195

Witt KA (2013) The Nutrient Content of Moringa oleifera Leaves. Messiah College Department of Nutrition and Dietetics:1-6. https://miracletrees.org/moringa-doc/nutrient-content-of-morin ga-oleifera-leaves.pdf

Xiong X, Yang X, Liu W, Chu F, Wang P, Wang J (2013) Trends in the treatment of hypertension from the perspective of traditional Chinese medicine. Evid Based Complement Alternat Med 2013(ID275279):1-13. https://doi. org/10.1155/2013/275279

Yang J (2020) Online academic conference of integrated TCM and western medicine on prevention and treatment of COVID-19. https://hd.guahao.com/n/26881. Accessed 23 Apr 2020

Wang J (2002) Analysis on the theory of chinese herbal flavor. J Anhui Univ Tradit Chin Med 21(1):4-6

Zaffer M, Ahmad S, Sharma R, Mahajan S, Gupta A, Agnihotri RK (2014) Antibacterial activity of bark extracts of Moringa oleifera Lam against some selected bacteria Pakistan. J Pharm Sci 27:1857-1862

Zhang Q, Hengshan S (2001) A practical Chinese-english dictionary of traditional Chinese medicine. Shandong Science and Technology Press, China

Zhang T, Liu C (2015) Identification of Chinese materia medica and its chemical biology characterization path on five taste theory[J]. Chin Tradit Herb Drugs 46(1):1-6

Zongo UZL, Savadogo A, Traoré AS (2013) Nutritional and clinical rehabilitation of severely malnourished children with Moringa oleifera Lam. Leaf powder in Ouagadougou (Burkina Faso). Food Nutr Sci 4:991-997

Publisher's Note Springer Nature remains neutral with regard to jurisdictional claims in published maps and institutional affiliations. 